Maurer School of Law: Indiana University

Digital Repository @ Maurer Law

1985

\title{
Crossing Boundaries: Nineteenth-Century Domestic Relations Law and the Merger of Family and Legal History
}

Michael Grossberg

Indiana University-Bloomington, grossber@indiana.edu

Follow this and additional works at: https://www.repository.law.indiana.edu/facpub

Part of the Family Law Commons, and the Legal History Commons

\section{Recommended Citation}

Grossberg, Michael, "Crossing Boundaries: Nineteenth-Century Domestic Relations Law and the Merger of Family and Legal History" (1985). Articles by Maurer Faculty. 2153.

https://www.repository.law.indiana.edu/facpub/2153

This Article is brought to you for free and open access by the Faculty Scholarship at Digital Repository @ Maurer Law. It has been accepted for inclusion in Articles by Maurer Faculty by an authorized administrator of Digital Repository @ Maurer Law. For more information, please contact rvaughan@indiana.edu. 


\title{
Crossing Boundaries: Nineteenth-Century Domestic Relations Law and the Merger of Family and Legal History
}

\author{
Michael Grossberg
}

This essay argues for the need to study the legal history of the American family. It does so by combining a critique of secondary literature in family and legal history with examples from nineteenth-century domestic relations law. These examples, drawn from family law doctrines on seduction under the cover of a marriage promise, runaway marriages, and bastardy, are used to indicate the benefits of adding a sociocultural dimension to legal history and legal and institutional dimensions to family history. Three main themes in the history of nineteenth-century domestic relations law are developed to make these points: the law's particular fabric of issues, its distribution of authorship, and its chronological development. These themes suggest why a full understanding of the legal history of the American family requires crossing the boundaries between legal and family history.

American family history and legal history have developed in isolation from each other. Despite more than two decades of intensive, pathbreaking work in both fields, the history of the law of the family exists primarily as a set of assumptions in casebooks and law review articles. The disinterest of lawyers and, more important, the predilections of family and legal historians explain its neglect.

The result is that a history of the law of the family does not exist. At the most basic level, that means that contemporary debates about law and family emerge out of a historical void. The absence of this history means that legal and family historians as well as legal scholars, lawyers, and others interested in family policy lack the perspective that only historical analysis can offer. The intent of this essay is to explain the value of investigating this unexplored

Michael Grossberg is assistant professor, Department of History; lecturer, School of Law, Case Western Reserve University. B.A. 1972, University of California, Santa Barbara; Ph.D. 1979, Brandeis University.

This paper was first presented at the Legal History Program, School of Law, University of Wisconsin, Madison in July 1984. My thinking on the subject has benefited from the comments on the paper by the participants in the program's Legal History of the Family Seminar and particularly those of Hendrik Hartog and Stanley Kutler. I have had helpful suggestions from my colleagues Carl Ubbelohde and David Hammack. 
past. That purpose can only be achieved, though, by first explaining the limitations of current scholarship in family and legal history and then suggesting why a full understanding of the legal history of the American family requires crossing the boundaries of those two fields.

Family historians have concentrated on locating evidence about the internal structure and relationships of past households. The interaction between families and external institutions, particularly public ones, are assumed or ignored. An anti-institutional bias, often tied to an anti-elite focus, has encouraged family historians to depict public authority and institutions as either static anachronisms, passive reflections of internal family change, undifferentiated agents of oppression and repression, or unheeded sets of elitist demands. ${ }^{1}$

The examples are endless. Though 20 years separate their work, the studies of divorce in the Progressive Era (1890-1920) by both William O'Neill and Elaine May ignore its legal context. ${ }^{2}$ Trying to locate sources of the period's great surge in divorce rates, O'Neill dwells on reformers who failed to stop the surge because they misunderstood the new personal nature of matrimony; May emphasizes the demographic and class context of family disruption. Neither deals with the willingness of trial judges to grant divorces through an expansive definition of mental cruelty. ${ }^{3}$ Thus, they not only ignore a major source of escalating divorce rates, they also fail to understand how judicial actions helped structure divorce proceedings by compelling couples and reformers to translate their discontent into legal forms and language.

The point is not that one body of information is more intrinsically important than others, but rather that historians must meld all relevant sources to understand a topic like divorce, which cuts across legal and family life. In other words, the sensitivity with which most historians traditionally approach other sources is missing in their use of legal materials. When noticed at all, the law is viewed merely as a data base, akin, perhaps, to census records. Statutes, trial records, appeals, administrative regulations, customary practices, and the other staples of the American legal order are then seized upon with little understanding of their institutional context and the nature of legal discourse. ${ }^{4}$

1. For attempts to place the family in an institutional context, though more in relation to the market than to other institutions, see Eli Zaretsky, Capitalism, the Family, and Personal Life (New York, 1976); Lise Vogel, The Contested Domain: A Note on the Family in the Transition to Capitalism, 1 Marxist Persp. 50 (1978); Tamara Hareven, Family Time and Industrial Time: The Relationship Between the Family and Work in a New England Industrial Community (Cambridge, 1982). For another assessment of this literature see Rosabeth Moss Kanter, Families, Family Process, and Economic Life: Toward Systematic Analysis of Social Historical Research, 84 Am. J. Soc. 316 (1978).

2. William O'Neill, Divorce in the Progressive Era (New Haven, Conn., 1967); Elaine Tyler May, Great Expectations, Marriage and Divorce in Post-Victorian America (Chicago, 1980).

3. In studying local court records Robert L. Griswold has recognized the importance of grounds like mental cruelty for the character of divorce litigation; see his Family and Divorce in California, 1850-1890, at 19-20, 212-13 (Albany, N.Y., 1982).

4. For a further discussion of this point see Michael Grossberg, Exploring the Legal Wilderness, 10 Rev. Am. Hist. 84 (1982). 
On a more general level, the most important recent synthesis of American family history, Carl Degler's At Odds: Women and the Family in America from the Revolution to the Present, dismisses through neglect the institutional context of family life, let alone the legal context. ${ }^{5}$ Advancing an argument regarding attitudes, he claims that the changing attitudes toward gender, sexuality, and the home themselves transformed family life. In this and similar assessments of family history, institutions (such as courts) and their creations (such as common law) are assumed to be reactions to change rather than parts of the process of change. It is no wonder, then, that the relationship between nineteenth-century families and the state remains largely unexamined by American family historians. But as historian Mary Ryan has argued, "[i]t is time to discard the blinders of domestic ideology and see the family as but one strand in the whole web of relations and institutions that constitute a society." 6

Thus, through misuse or neglect family historians have failed to understand the legal dimension of their subject. By doing so they have also ignored a major resource for the history of the American family. According to historian Lawrence Stone, the "vast body of data in the records of ecclesiastical or other courts dealing with litigation over breach of contract, separation, or divorce . . . may . . . turn out to be the single most important untapped body of qualitative information about family life in the past." "Yet such legal records must be used carefully and in context. Unfortunately, legal historians offer family historians little assistance in doing so.

Legal historians have also ignored the law of the family. Until quite recently, a set of research priorities grounded in commercial transactions-and replicating the law school curriculum-has dominated legal history. Willard Hurst, the founder of modern American legal history, noted in a 1982 review of the field: "So far as research has broken out of those bounds [the treatment of law as a self-contained system], it has tended to give most attention to relations of law to the changing character of the private market." As a result, whether they operate under the functionalism of the Hurst school, the class-conflict model of Morton Horwitz, or the eclectic approaches like those of William Nelson, legal historians have tended to discount the study and appreciation of social values and cultural practices that were not clearly commercial in nature. They have thus generally bypassed such topics as the family, religion, and immigration in favor of property, torts, and other more obviously market-related subjects. ${ }^{9}$

5. Carl Degler, At Odds: Women and the Family in America from the Revolution to the Present (New York, 1980).

6. Mary P. Ryan, The Explosion of Family History, 10 Rev. Am. Hist. 191 (1982).

7. Lawrence Stone, Family History in the 1980s: Past Achievements and Future Trends, 12 J. Interdisciplinary Hist. 51, 83, and see 52 (1981). Stone points out that French social historians have used such records for quite some time. For an example of the French work see Emmanuel Le Roy Ladurie, Family Structures and Inheritance Customs in Sixteenth Century France, in Jack Goody, John Thirsk, \& Edward P. Thompson, eds., Family and Inheritance (Cambridge, England, 1976).

8. Willard Hurst, The State of Legal History, 10 Rev. Am. Hist. 293 (1982).

9. For a critical discussion of this issue see Lawrence M. Friedman, The State of American Legal History, 17 Hist. Teacher 113 (1983). 
Beyond the perfunctory treatment of the topic in legal history monographs and general legal histories, perhaps the clearest statement of the unimportance of the law of the family to legal historians is that it is absent from the contents of the only legal history casebook: Both Stephen Presser and Jamil Zainaldin have published articles on adoption, yet they left domestic relations entirely out of their volume. ${ }^{10}$ Similarly, in his seminal 1960 Thomas M. Cooley lectures, later published as Law and Social Process in United States History, Hurst dismissed family law as not worthy of study because, he assumed, the law played a marginal role in domestic relations. ${ }^{11}$ By 1982, though, the impact of social and family history on his thinking could be discerned. He still maintained that the market should be the focal point of legal history, but conceded that the focus should be widened: "social reality requires that legal historians pay more attention to the interplay of law and the family and sex roles, the bearing of law on the church, on tensions between conventional morality and individuality, on education, and on the course of change in scientific and technical knowledge."12

Yet doing so requires that legal historians expand their frame of analysis, not merely their subject matter. Despite neglect of noncommercial law, most legal historians seem to assume that the history of all branches of the law replicates that of commercial law. Horwitz's 1976 Transformation of American $L a w$ is a case in point. ${ }^{13} \mathrm{He}$ included dower, a topic from domestic relations law, among the examples of the post-Revolutionary transformation of American law. But he analyzes dower only as evidence of his larger thesis about the entrepreneurial biases of commercial law. In this case, he argues, legal rules were changed to ensure that widows did not keep productive land out of the market. Horwitz does not consider dower as an example of a different legal domain or consciousness as some women's historians who have studied dower rights have suggested. Suzanne Lebsock, for example, contends that women in antebellum Petersburg, Virginia, occasionally traded dower rights for separate estates, not as part of their fight for equality or autonomy but as "protection from gross exploitation." 14 In other words, family law topics such as dower can open a set of concerns bound up with social reproduction, not merely with market developments. ${ }^{15}$ And again the issue is not exclusivity but multiplicity of approaches. Without widening the framework of analysis in legal history, legal historians can neither fully ex-

10. Stephen Presser \& Jamil Zainaldin, Law and Aimerican History (St. Paul, Minn., 1980).

11. James Willard Hurst, Law and Social Process in United States History, esp. 8-9 (Ann Arbor, Mich., 1960).

12. Hurst, supra note 8, at 293-94.

13. Morton Horwitz, The Transformation of American Law 56-68 (Cambridge, Mass., 1977).

14. Suzanne Lebsock, The Free Women of Petersburg 79, and see 77-79 (New York, 1984). For another example of a historical approach to dower see Linda Kerber, Women of the Republic: Intellect and Ideology in Revolutionary America 123-36 (Chapel Hill, N.C., 1980).

15. By social reproduction I mean the system of institutions and practices by which people are produced, the life cycle is organized, and the class, race, and gender systems are reproduced. For a discussion of this question see Richard Busacca \& Mary P. Ryan, Beyond the Family Crisis, 3 Democracy 80-81 (1983). 
plore topics like the family nor fruitfully aid social historians struggling to find meaning in legal records. Put more directly, the law of the family may provide a particularly compelling vehicle for merging lawyers' legal history, which concerns legal theory and institutional form, with historians' legal history, which concentrates on social and economic context.

The predilections of family and legal historians can, and should, be joined. Now may be the time to begin. When read in tandem, recent scholarship in legal and family history suggests that an intermingling of the fields can have compelling results. In their separate domains, family and legal historians ask a common set of questions about the nature of institutional autonomy, the basis of periodization, the sources of change, the difficulties of treating analytical constructs such as the family or the legal system as concrete realities, and the legitimacy of considering each institution as a dependent or independent historical variable. A merger of the two fields can illuminate both of them by probing questions of substance and method as well as questions about the implications of categorization itself. ${ }^{16}$ And on a larger scale, such a merger can give current debates on abortion, spousal responsibilities, children's rights, and the regulation of sexuality a history. Far too often those debates proceed from assertions about the uniqueness of contemporary conflicts. A glance backward reveals not only how fallacious such assumptions are, but also how the past has helped structure the present.

The law of domestic relations, one casualty of the inattention to the legal history of the family, documents the benefits of merging legal and family history. In nineteenth-century America, laws on the family ceased to be undifferentiated rules drawn from disparate fields-land law, settlement policies, debtor-creditor rules, and ecclesiastical regulations. They became a new corpus of law, the "law of domestic relations." Neither lawyers nor historians have recognized this momentous shift and its historical and contemporary implications. ${ }^{17}$ This essay suggests why they should and why a full understanding of this and other facets of legal history of the American family requires crossing the boundaries of family and legal history. It does so by combining a critique of secondary literature in family and legal history with examples drawn from nineteenth-century domestic relations law dealing with sexuality, marriage, and family forms. ${ }^{18}$

In the shopworn words of book reviewers, the intent here is to be suggestive not persuasive. The main purpose is to use domestic relations law to suggest to both legal and family historians the benefits of exchange between the two fields. Secondarily, the essay hopes to demonstrate the potential contri-

16. Such an endeavor is the goal of the current program in the History of the Law of the Family at the School of Law, University of Wisconsin, Madison, at which this paper was first presented.

17. For a nineteenth-century assertion about the distinctive nature of family law practice see Joel $P$. Bishop, First Book of Law 216 (Boston, 1868).

18. The following analysis is drawn from a much larger work on the topic; for a more thorough discussion of the issues raised in this paper see Michael Grossberg, Governing the Hearth: Law and the Family in Nineteenth Century America (Chapel Hill, N.C., 1985). 
butions such a history can make to understanding the character of contemporary policy debates over the family.

To help open the subject to further examination, three themes in the creation of an American law of domestic relations will be discussed: the particular set of issues in the legal discourse on the family; the various authors of the law; and the nature of the law's particular sequence of change or periodization. These themes have been selected because they reveal some central characteristics of nineteenth-century domestic relations law and suggest its potential contribution to the history of law and the family.

\section{THE FABRIC OF IsSUES IN}

\section{Nineteenth-Century Domestic Relations LaW}

The first theme in this examination of history and historiography concerns the issues that dominated the nineteenth-century construction of an American domestic relations law. As in all categories of the increasingly compartmentalized legal order, these were a changing, occasionally discordant amalgam. Many were not uniquely bound to family questions. What is important to stress, though, is that domestic relations law, like each category of law, had a particular set of issues that framed its discourse. The most significant of these were gender, race, anticommercialism, economic development, the use of litigation for resolving family disputes, poverty and dependency, family uniformity, class, and ethnicity. These issues appeared in various combinations reflecting different priorities in different domestic relations controversies. And the special fabric of issues had a temporal aspect as well. Many issues, such as a determination to protect family property and promote capital accumulation, reflected age-old concerns in family governance; others, such as an obsession with family uniformity and racial purity, had peculiarly nineteenth-century origins. The significance of these issues lies less in their identity as exact sources of American domestic relations law than in their collectively constituting a special fabric from which the discourse about the law emerged.

Examining this fabric of issues can enhance our understanding of legal and family change in nineteenth-century America. It provides a mechanism for using what historian Fred Matthews calls a "multivariate approach" to historical analysis: a way to identify a constellation of causal forces rather than a single source of change. Matthews does acknowledge an important caveat though: it is "quite possible that richer, more multivariate paradigms will tend to greater technical imprecision than will tight, limited accounts of one kind of cause leading to one kind of effect. But rigor may be achieved at the cost of ruling out what does not fit well." 19

Nevertheless, using a multivariate approach to the history of nineteenthcentury domestic relations opens up new perspectives on legal and family history-particularly in legal history, where sociocultural influences have often 
been ignored. For example, by comparing the fabric of issues in domestic relations law with that of other legal categories, similarities and differences across the legal order can be more clearly isolated. Until now the commercial law focus of most legal history has stymied such cross-category comparisons in part because it has often rested on variants of economic determinism at the expense of other causal factors. But a multivariate approach to legal change, particularly one that looks beyond a narrowly defined market and accepts the validity of attitudinal and other cultural sources of change, can help locate the distinctive and common features of domestic relations law. Indeed, research in family history demands that such an approach be taken. After insisting that work in family history has demonstrated the influence on household development of psychological attitudes as well as economic functions, social structures, and demographic changes, historian Lawrence Stone declared that on both sides of the Atlantic "these attitudinal changes can be proved to have occurred before the economic changes, and in classes unaffected by those changes, and therefore must to some extent have enjoyed an independent history. Reductionist attempts to attribute them all to economic causes do not fit the historical facts." 20

Similarly, adopting a multivariate approach can aid a merger of legal and family history by adding a new element to family history: the translation of household affairs into legal discourse. In this way, the relationship between internal family changes, so prominent in family historiography, and external institutions can be examined more directly. Besides indicating something about the character of a history of the law of the family, this fabric of issues thus also displays some of the larger benefits to be derived from a merger of family and legal history. The issues suggest that legal historians can use family history to provide a sociocultural dimension, thus helping them avoid the economic reductionism so pervasive in American legal history. Conversely, they indicate that legal history can suggest to family historians the need to be sensitive to institutional considerations. Such a combination should produce a historical analysis that can provide nonhistorians with a clearer sense of history of the law of the family.

\section{Courtship, Seduction, and the Issues of Domestic Relations Law}

The changing judicial treatment of damage suits by seduced and abandoned brides provides one illustration of these contentions. Adhering to traditional legal rules, post-Revolutionary judges generally rejected the claims of jilted women who filed breach of marriage promise suits. These abandoned brides insisted that seduction warranted additional damages from their former lovers. By the 1840 s, though, the bench had begun to reevaluate that traditional legal policy. Judicial revision changed the common law of seduction and now helps us identify a part of the special fabric of nineteenthcentury domestic relations law. 
Post-Revolutionary judges rebuffed attempts by women to introduce evidence of seduction to increase damage awards. They invoked the old common law rule that a female could not file such a suit. Only a woman's father, guardian, or master could receive damages; a legal fiction asserted that these men were the real sufferers since they stood to lose her services. An unmarried woman in the traditional hierarchy of the family, in effect, held the status of servant in all households in which she lived. Older sentiments toward sexual morality, which assumed both sexes to be willing, eager, and thus equally guilty participants in illicit intercourse, buttressed the judicial conclusion. ${ }^{21}$

South Carolina Justice Joseph Brevard relied on the standard common law rules in 1804 to dismiss the claim of Rebecca Frost that her seduction by George Marshall, after his repeated pledges of love and proposals of marriage, warranted additional compensation. To do otherwise, he asserted in a traditional paternalistic admonition, would allow a woman

to take advantage of her own frailty and turpitude; and might have a tendency to encourage lewdness, and the law might be in some measure subservient to the designs of artful women of loose morals, who may be inclined to sacrifice their virtue on slight solicitation, listening rather to the suggestions of their own libidinous passions, than trusting to the promises of a favored lover.

In 1843, Chief Justice John Bannister Gibson of Pennsylvania dismissed another woman's plea with the caustic observation: "Every girl who is silly enough to surrender her citadel of virtue to her lover, on the credit of general professions of love, is silly enough to believe that she is going to be married out of hand; and it must not be forgotten that professions are not promises." Adhering to a dogmatic common law construction of individual responsibility under the ancient maxim volenti non fit injuria [one who consents cannot recover], judges depended on their own methods to reward sexual purity and punish sexual weakness. ${ }^{22}$

Dogmatic declarations like Gibson's, however, became more unusual in midnineteenth-century America. Decisions, treatises, and articles reveal a growing uneasiness with the assumption of equal responsibility at the heart of the traditional common law doctrine. Views like Gibson's began to run counter to an emerging image of courting females and to new conceptions of the place of breached marriage-promise suits in family law. These developments help identify a combination of issues in nineteenth-century family law that began to undermine the older view of seduction under the cover of promise to wed.

21. For a discussion of these issues see John Demos, A Little Commonwealth 152-54, 157-59 (New York, 1970); 2 George Howard, A History of Matrimonial Institutions 180-86 (3 vols. Chicago, 1904); Howard Gadlin, Private Lives and Public Order: A Critical Review of Intimate Relations in the United States, 17 Mass. Rev. 304-6 (1976).

22. Frost v. Marshall, 2 S.C.L. (2 Brev.) 114, 115-16 (1804); Weaver v. Bachert, 2 Pa. 80, 81-82 (1843); and see Burks v. Shain, 5 Ky. (2 Bibb.) 341 (1811); Hay v. Graham, 8 Watts \& Serg. 27 (Pa. 1844); Perkins v. Hersey, 1 R.I. 493 (1851); Baldy v. Stratton, 11 Pa. 316 (1849); Tapping Reeve, Baron and Femme 241-43 (New York, 1816). 
Since their medieval introduction, breach of promise suits have been curious legal hybrids that combine tort and contract in an effort to police courtship and compensate nuptial losers. The unique legal pedigree of the suit reflected a continuing conception of marriage as a simple contract. Since, as dictated by common law governance of families, lovers policed their own courtship, the courts came to the aid of a jilted man or woman only when he or she complained. Post-Revolutionary American judges incorporated the suit into domestic relations law as part of their contractual concept of matrimony. ${ }^{23}$

Breach of promise suits proved attractive to these authors of domestic relations law for a variety of interrelated reasons. For its aristocratic and gentry users in England and provincial America, the suit had protected the property transactions and dynastic interests that governed arranged marriages. In the post-Revolutionary legal order, though, breach of marriage-promise suits allowed the courts to promote different notions of marriage and gender responsibilities. Indeed, the suit performed new functions amidst a broader reevaluation of matrimony itself. As literary analyst Jay Fliegelman suggests in his study of the era's social ideology: the question as to

whether marriage was a property transaction between father-in-law and suitor or a sacred contract between lovers was a very real one in nineteenth-century America-one that reflected a larger debate as to whether property or personal rights were more sacred, as to whether the possession of the former or the exercise of the latter conferred upon men a more real independence. ${ }^{24}$

Once matrimony was conceived as a personal relationship between two lovers, the law began to leave individual suitors freer to make their own marital choices. But once marital pledges had been exchanged they became legally binding and actionable contracts. Subsequent suits offered judges an opportunity to encourage a free-market view of matrimony akin to but different from the one they advanced in commercial-contract disputes. In family law, contractualism provided a common law means of punishing nuptial transgressors. Judges redrew the traditional, property-bound law of courtship. The action then enabled them to promote prudent legal behavior by creating special domestic relations rules affirming the responsibility of every individual to fulfill voluntarily assumed family responsibilities. Courts used the threat of judicially imposed punishment to deter the careless and the reckless. In that manner, a New Jersey judge in 1797 instructed beaux: "Let them be cautious in making no promises, except such as they intend to perform, or for the nonperformance of which they shall be liable to assign a sufficient reason and they will be perfectly safe." 25

23. Robert C. Brown, Breach of Promise Suits, 77 U. Pa. L. Rev. 474 (1928-29); Robert Helmholz, Marriage Litigation in Medieval England 31-36 (London, 1974); 3 Howard, supra note 21, at 200-203; Geoffrey May, The Social Control of Sexual Expression 248-49 (New York, 1931); W. S. Brockelbank, The Nature of the Promise to Marry: A Study in Comparative Law, 41 Ill. L. Rev. 199-213 (1946).

24. Jay Fliegelman, Prodigals and Pilgrims: The American Revolution Against Patriarchal Authority, 1750-1800, at 131 (New York, 1982).

25. Peppinger v. Low, 6 N.J.L. 386 (1797). 
Equally important, the action allowed the courts to translate the era's gender assumptions into binding rules. It is in views toward gender that a portion of the distinctive fabric of issues in domestic relations law becomes clear, particularly the role that ideal images of family members have.played in legal change. In colonial America both sexes had filed breach of promise suits; not so in the post-Revolutionary Republic. In this formative era of domestic relations law, breach of marriage-promise suits were brought by women. The suits acquired a new base: majoritarian nineteenth-century assumptions about naturally ordained gender roles and traits. At a time when observers like Tocqueville marveled at the freedom given courting couples, nuptial liberty led to sharper judicial images of brides and grooms. Judges concluded that because the male was more independent and worldly, he incurred greater legal liabilities, while the politically and economically circumscribed female's culpability declined. With its blend of contractual entrance and tortious exit, the suit thus elicited judicial approval as an appropriate means of assuaging an injured woman's feelings within a privatized family law. A woman's right -or perhaps better put, a woman's need - to marry became the primary justification for breach of promise suits. In 1846 the Alabama Supreme Court asserted without fear of dissent: "By strict rule the action is common to either sex, though in our country, a just regard to public morals has long since confined the action alone to the female sufferer. ${ }^{\prime 26}$ Such declarations reveal both the presence and the role in legal sources of conceptions of the family and its members. Locating such images filtered through the law can help historians, lawyers, and legal scholars understand the sociocultural dimension of legal change and the relationship between it and external developments.

The breach suit also points out the pervasive yet distinctive influence of contractual ideology on domestic relations law-a point that warrants emphasis. As Lawrence Friedman has explained, the contract reigned as the dominant nineteenth-century metaphor for legal relations of all kinds in a society dominated by individualistic social, economic, and political philosophies. Yet his study, like most nineteenth-century legal history, draws almost exclusively on commercial law for evidence. The contract did serve as a way of conceptualizing most domestic relations too, but in a distinctive manner. Breach of promise cases, for instance, indicate that the judiciary recognized the gap between the law's theoretical assumptions of contracting equality between men and women and the realities of feminine powerlessness. Indeed, in these cases a new legal fiction arose, as influential in domestic relations as were fictions like the "reasonable man" that Friedman and historian Leonard Levy emphasized in their analysis of commercial-contract disputes

26. Kelly v. Renfro, 9 Ala. 325 (1846); for a similar analysis of the judicial role in divorce suits see Jane Turner Censer, "Smiling Through Her Tears": Ante-Bellum Southern Women and Divorce, 25 Am. J. Legal Hist. 24 (1981). 
and railroad liability suits. ${ }^{27}$ The "prudent courting couple," a pair that carefully weighed the legal implications of all their statements, plans, and preparations, populated breach of promise suits.

The "prudent courting couple" joined "the fit parent," "the cared-for child," and "the proper spouse" in domestic relations law's cast of fictions. In breach of promise cases, custody disputes, and divorce actions, these judicial creations translated assumptions about the family into governing legal rules. They served as legal expressions of what historian Ryan has called "family symbolism"; that is, the widely held perception among Americans (despite a contrary reality) "of the family first of all as a husband, wife, and children who reside together in what they see as a natural, rather than a socially-constructed unit." 28 The fictions show how legal sources address this central topic in family history, and they help us chart the public image of the family. The primary image-the private home of husband, wife, and their children-figures quite prominently in legal materials; yet variations on that image, such as the bastard family to be discussed below, are evident as well. A study of varying and conflicting primary images of the family can, thus, expand our understanding of how views of the family change and how the changes are translated into law.

Breach of marriage-promise litigation also discloses a fear of male coercion, another distinctive thread in the fabric of issues in domestic relations law. A pervasive influence on family law from courtship to probate, judicial concern about male coercion of women stemmed both from the realities of feminine powerlessness in the era and from rigid views of gender. Judges considered women a dependent class, hardly a novel view in AngloAmerican history. But this article of faith had dramatic consequences in the legal culture of nineteenth-century America. As part of their characterization of various actors in domestic relations litigation, judges began to assert that women had both a particular claim on the conscience of the bench and a special set of rights independent of either property ownership or male prerogatives. Again the contrast with studies of commercial law is pertinent. Though in different explanatory contexts, both Horwitz and Friedman stress the primacy nineteenth-century contract law gave to the will of contracting parties. Domestic relations actions, like breach of marriage suits, suggest that this "will theory" may have been a peculiarly male concept in some areas of the law. Voluntary contractual agreements appear to have been less binding on betrothed women than on betrothed men. ${ }^{29}$

27. Lawrence M. Friedman, Contract Law in America (Madison, Wis., 1965); Leonard Levy, The Law of the Commonwealth and Chief Justice Shaw ch. 9 (New York, 1957). Unlike the gender-based distinctions evident in the breach of promise cases, both Friedman and Levy point out the incongruity between judicial assumptions about the theoretical and actual bargaining position of workers and employers.

28. Ryan, supra note 5, at 186; and see Steven Mintz, A Prison of Expectations: The Family in Victorian Culture (New York, 1983).

29. For examples of such judicial sentiments in breach of marriage cases, see Capehart v. Caradine, 4 Strob. Eq. 42, 46 (S.C. 1849); Gaskill v. Dixon, 3 N.C. (2 Hayw.) 536 (1805); and see Keith Thomas, The Double Standard, 20 J. Hist. Ideas 195 (1959). For a discussion of the will theory of contract in commercial law see Horwitz, supra note 14, at 22-26. 
Though hardly noticed by family historians, who have generally ignored institutional conceptions of household members, this partial legal capacity of women played a significant role in family law. It also took a variety of forms. In breach of promise suits it is related to the emergence of free choice and romantic love as courting norms. As historian James Henretta has asserted, when affection and emotional commitment became the sources rather than the product of matrimony, traditional arranged marriages gave way to "sexual relationships based largely on the free choice of those involved; and . . . this kind of more personal and more romantic union steadily became more important." ${ }^{30}$ In Wightman $v$. Coates (1818), Massachusetts Chief Justice Theophilus Parker succinctly described why women's partial legal capacity should affect breach of promise cases at a time when courting couples seized control of matrimonial decision making: "the delicacy of the sex, which happily in this country gives man so much advantage over women in the intercourse which leads to matrimonial engagements, requires for its protection and continuance the aid of the laws." ${ }^{31}$

A change in the common law of seduction indicated by the growing aversion to declarations like that of Pennsylvania Chief Justice Gibson in 1843 demonstrates how judges wove these various strands into domestic relations law. As early as 1807, the Massachusetts Supreme Judicial Court in Paul v. Frazier had accepted a woman's contention that seduction and pregnancy under the cover of a promise of marriage merited additional compensation. But it was a disingenuous ruling without clear sources or immediate impact. ${ }^{32}$

In 1834, though, the Missouri Supreme Court resurrected Paul v. Frazier to legitimate its break with the traditional common law of seduction. Acknowledging the weight of contrary authority, the Missouri justices nevertheless wielded their discretionary powers and proclaimed the right to decide the issue anew while reviewing another breach of promise case involving a pregnant woman. They rested their opinion on a new reading of the judicial obligation to protect the public welfare by claiming that the "only obvious effect must be to induce persons to execute their contracts of marriage, where seductions have ensued from them, for fear of being compelled to answer in damages for the pain and ignominy which the breach of such contracts would bring upon the victims of their lust and fraud." ${ }^{33}$ The court also objected to the absence of a feminine right to sue in such cases, thus joining in the creation of a nineteenth-century judicial paternalism that favored distinct common law privileges for women:

30. James Henretta, The Evolution of American Society 133 (Lexington, Mass., 1973); and see Daniel Scott Smith, Parental Power and Marriage Patterns: An Analysis of Historical Trends in Hingham, Massachusetts, 35 J. Marriage \& Fam. 462-75 (1973).

31. 15 Mass. 3 (1818); and see Nancy Cott, The Bonds of Womanhood: Woman's Sphere in New England, 1750-1835, at 77-83 (New Haven, Conn.,1977); Degler, supra note 5, ch. 2.

32. 3 Mass. 71 (1807); and see Whalen v. Laymen, 2 Blackf. 194 (Ind. 1828); 1 Zephania Swift, A System of Laws of the State of Connecticut 188 (2 vols. New Haven, Conn., 1795).

33. Green v. Spencer, 3 Mo. 225, 227 (1834). 
nor is it a reason why the daughter should not be permitted to recover on the breach of a marriage contract, that her father may give it in evidence and recover in his action for the same seduction. Money can afford but a paltry and inadequate compensation for the loss of virtue and character of the child; or for the loss of the child's society, and the peace and happiness of the family, to the parent. They each suffer injuries to themselves, and for which they should have redress. ${ }^{34}$

A strident dissent in a companion case that charged the majority with using faulty precedents and forging bad policy went unheeded..$^{35}$

Arguments like that of the Missouri court won more and more converts in midnineteenth-century America. An 1850 decision in New York upholding an award of additional compensation to yet another pregnant woman indicates its appeal. ${ }^{36}$ The judges not only insisted that women had a separate legal identity and thus a right to assert their own claims, but also that the sensibilities of the two sexes differed. They relied on a 1783 English court decision and the theories of English moral philosopher William Paley, who championed sexual restraint and feminine meekness to distinguish between the moral guilt of men and women. In the New York case the court declared unequivocally that the "female and her seducer do not stand on equal ground. She is the weaker party and the victim of his acts, and the seduction has been practiced upon her under the false color of a promise of marriage which he never intended to perform." 37

As seduction ceased to be considered an act of mutual consent and women's subordinate legal status no longer prevented their filing suit, the moral and legal right of women to claim additional compensation became a basic principle of American family law. An 1880 Michigan ruling, Bennett $v$. Beam, explained why.$^{38}$ Mary Beam accused her lover of seducing her with the pledge that they would wed as soon as he finished building several buggies. They did not, and she sued. The court reaffirmed a judgment in Beam's favor with the added admonition:

In many cases, the loss sustained for a breach of the agreement to marry may be slight indeed; but never can that be the case where the life-long blight which seduction entails enters the case. Respectable society inflicts upon the unfortunate female a severe punishment for her too confiding indiscretion, and which the marriage would largely if not wholly have relieved her from. The fact of seduction should therefore go a great way in fixing the damages, as in no other way would amends be made to the plaintiff for the injury sustained, or the defendant properly punished for his aggravated offense. It would seem also to be in full accord with the sense of justice implanted in the head of every right, high-minded person and therefore within the reason of the common law. ${ }^{39}$

34. Id.

35. Hill v. Mupir, 3 Mo. 228 (1834).

36. Wells v. Padget, 8 Barb. 323 (N.Y. 1850).

37. Id. at 325 .

38. 42 Mich. 346 (1880).

39. Id. at 351; and see Espy v. Jones, 37 Ala. 379 (1861); Sayer v. Schulenberg, 33 Md. 288 (1870); Smith v. Braun, 37 La. Ann. 225 (1885); Haymond v. Saucer, 84 Ind. 3 (1882); Bird v. Thompson, 96 Mo. 


\section{Historiographical Implications}

The shift in the law governing seduction under the cover of a marriage promise was woven into the fabric of issues of nineteenth-century domestic relations law. It illustrates the kind of insight into legal and family history that the law of the family can provide. For example, in the attempt to restrain sexual excess, many Victorians stressed the passionlessness of normal women; some advice writers even denied women sexual feelings at all. The image of the desexualized woman is an example of a topic that has been debated rather thoroughly by historians in ways that have implications for legal history; simultaneously, it is a topic in which legal sources may be used to widen the discussion. By focusing current historical research into sexuality on the notion of feminine passionlessness, historians are seeking to understand the relationship between behavior and ideology. In fact, Degler argues that "sexuality is to women's oppression what color has been to black oppression." 40 Differences persist among historians over whether social conceptions, such as passionlessness, were mere prescription or reflected part of the reality of feminine sexuality. But like the growing scholarship on dower, the debate itself raises important questions and offers useful methods for understanding the relationship between ideas and behavior in sociocultural questions. Historian Nancy Cott, for example, contends that passionlessness may have been a strategy adopted by married women to gain autonomy within the home. ${ }^{41}$

Conversely, the debate among family and women's historians is limited by a tendency to ignore what historian Estelle Freedman terms "sexual politics." By that she means subject matter including "political efforts to transform sexual thought or practice (for example, moral reform, antiprostitution, or birth control movements)" and interpretative issues such as "relations of power, particularly those based on class and gender." ${ }^{42}$ Legal records, like those from the breach of promise cases, offer just such a perspective on the issue. They indicate that in varying degrees, one powerful group of nineteenth-century Americans, the state appellate judiciary, not only accepted the new conception of women, they made the law conform to it in a variety of ways. The judicial use of legal penalties to promote a code of chaste conduct and enforce it on both men and women within the larger sexual double standard thus documents one translation of social ideology into concrete rules of law..$^{43}$

424 (1885); Kurtz v. Frank, 76 Ind. 594 (1881); Wilds v. Bogan, 57 Ind. 453 (1877); Kniffen v. McConnell, 30 N.Y. 285 (1864); Cotes v. McKinney, 48 Ind. 562 (1874); Giese v. Schultz, 53 Wis. 462 (1881); Giese v. Schultz, 65 Wis. 487 (1886); Giese v. Schultz, 69 Wis. 521 (1887); William Bullock, The Law of Domestic Relations of the State of New York 250 (Albany, N.Y., 1898).

40. Carl Degler, Women and the Family, in Michael Kammen, ed., The Past Before Us 320 (Ithaca, N.Y. 1980).

41. Nancy Cott, Passionlessness: An Interpretation of Victorian Sexual Ideology, 1790-1850, 4 Signs 219 (1978).

42. Estelle Freedman, Sexuality in Nineteenth Century America: Behavior, Ideology, and Politics, 10 Rev. Am. Hist. 196-97 (1982).

43. For a discussion of the issue see Degler, supra note 5 , chs. $9,11$. 
Equally important, the bench used a particular form of reasoning to explain the doctrinal change. Judges redefined seduction as victimization that sprang from the passion and deceit of males and then emphasized the passivity of women and an innate feminine instinct for a selfless life as wife and mother. According to the Illinois Supreme Court, "it is possible but hardly probable that a case may arise where the parties are equally guilty." ${ }^{44}$ By considering sexual relations inherently exploitive because of female dependency and male predation, the bench tried to align the law with the Victorian campaign to restrain sexuality. In fact, the judicial debate over seduction under the cover of a marriage promise appears to parallel, in perhaps telling ways, the midnineteenth-century feminist debate over prostitution; judges and feminists both stressed ownership and possession, the idea of one person holding another as property, as the "quintessential sexual terror." 4 s In related ways, that is, both groups assumed the autonomous individual to be the norm and considered dependency in terms of ownership and control the greatest threat to individual liberty. Stressing sexuality as the chief feminine trait and sexual vulnerability as the prime feminine liability led judges and feminists to view seduction and prostitution as the most fatal feminine disasters. It is such interconnections that a merger of family and legal history can reveal and assess.

The new seduction rules also highlight the differentiation of roles within the family in nineteenth-century domestic relations law. Most significant, though, breach of promise suits underscore the complex nature of that critical legal development. They suggest that far from merely documenting the rise of autonomous individualism - as so many present-day family lawyers and some historians seem to assume-temporal, gender, age, class, and a variety of other factors influenced the creation of separate legal identities within the family.

Indeed, the breach cases indicate that we must be much more critical of assertions that every increase in individual legal rights be considered a benchmark of progress. The creation of formal legal rules that compel women (and men and children) to face the unmediated forces of the market and society cannot be simply deemed beneficial. They must be demonstrated to be so. In breach of promise cases, it is true, the bench ceased to consider women as complete dependents without independent rights of redress when wronged. Yet, like other women's rights developments of the era, particularly the married women's property acts and the passage of legislation giving single women the right to sue their seducers, the judicial conferral of legal independence for women in breach cases constituted more a recognition of women's increased family responsibilities than an expansion of their sphere into commerce or politics. The seemingly contradictory recognition of feminine legal

44. Tubbs v. Van Kleek, 12 Ill. 446, 465-66 (1874); and see Fidler v. McKinley, 21 Ill. 308 (1859); 1 Theophilus Parsons, Jr., The Law of Contracts 553 (2 vols. Boston, 1853-55).

45. Ellen Carol Dubois \& Linda Gordon, Seeking Ecstasy on the Battlefield: Danger and Pleasure in Nineteenth Century Feminist Thought, 9 Feminist Stud. 8-9 (1983). 
rights alongside sexual passivity and victimization was reconcilable, as family historians have clearly documented, only by the Victorian ideal of women, which consigned them to a separate sphere with a combination of domesticity, moral superiority, sexual control, and dependent individuality. The separate-spheres analysis, now an orthodoxy of women's history, illuminates the issue because it explains the rigid definitions of gender roles at the heart of nineteenth-century family ideology and practice. ${ }^{46}$

Yet family historians have ignored the institutional aspects of this feminine sphere. They have explained it instead primarily as a social and cultural construct that had its greatest impact on internal family roles because of its demand for homebound feminine responsibilities and worldly male ones. Debate continues over whether this domestic sphere was purely repressive or helped create new opportunities for feminine self-identity and feminism. But as Degler argues, "to ask whether domesticity was principally a matter of social control-or one of social identification for women is to miss the complexity of women's place in the family in the past." ${ }^{47}$ Again sources from institutions, like the courts, that dealt with families illuminate part of the past complexity. The breach cases reveal the creation of a feminine legal sphere within domestic relations law. The cases indicate that a redefinition of women's legal status, such as the rejection of the notion of property rights in persons at the heart of the old seduction policy, did not lead to gender equality but rather to distinctive treatment; or to put it in the parlance of present-day constitutional rhetoric, nineteenth-century judges, like their late twentieth-century heirs, refused to consider classification by gender a "suspect" form of legal distinction.

A distinct set of rights tied to the special role thought of as naturally designed for women marked the new feminine legal sphere. Evidence that there was such a sphere comes not only from changes in seduction damages but also from a few of the existing studies of women and the law. The work by Lebsock, Zainaldin, Basch, Salmon, Chused, and a few others identify additional features of that sphere: maternal custody preference, married women's property rights, feminine will-making strategies. ${ }^{48}$ Clarifying the

46. The separate-spheres conception of gender roles was grounded in the assumption that the primary role of a married woman was the care of children and maintenance of the home. As the mistresses of the home, women were perceived by society and themselves as the moral superior but social legal inferior to their husbands. The organizational basis of the spheres led women to spend their time in the home, men in the marketplace. It is this sharp division of gender roles that historians have used as the basis of the separate-spheres argument. See Degler, supra note 5, chs. 1-2; Daniel Scott Smith \& Michael Hindus, Premarital Pregnancy in America, 5 J. Interdisciplinary Hist. 553-62; Carol Smith-Rosenberg, Beauty and the Beast and the Militant Woman, 33 Am. Q. 563-64 (1971); Charles Rosenberg, Sexuality, Class, and Role in Nineteenth Century America, 25 Am. Q. 138 (1973); Richard H. Chused, Married Women's Property Law: 1800-1850, 71 Geo. L.J. 1359 (1983).

47. Degler, supra note 40, at 320; and see Stone, supra note 7, at 65-66.

48. Jamil Zainaldin, The Emergence of a Modern American Family Law: Child Custody, Adoption and the Courts, 1796-1851, 73 Nw. U.L. Rev. 1038 (1979); Marylynn Salmon, The Property Rights of Women in Early America (Ph.D. diss., Bryn Mawr, 1980); Lebsock, supra note 14; Chused, supra note 46; and see Griswold, supra note 2; Bertram Wyatt-Brown, Southern Honor, Ethics and Behavior in the Old South (New York, 1982), esp. pt. 2; Grossberg, supra note 18. 
nature of this feminine legal sphere is the kind of significant contribution the legal history of the family can add to legal and family history.

The breach suits also suggest how a history of domestic relations can provide new sources for what might be termed popular consciousness, particularly legal consciousness. The suits record a set of strategies: feminine efforts to secure compensation for dashed nuptial hopes, male schemes to protect their pocketbooks, and judicial attempts to rationalize legal conduct. Each strategy offers a special window onto the consciousness-the values, desires, fears-of women and men in the past. Similarly, the shift in seduction rules documents the powerful role of beliefs in shaping and constructing an American domestic relations law. Beliefs such as feminine victimization and sexual passionlessness acted as both stimulants and blinders. They encouraged and channeled innovation; domestic relations law offers numerous examples of this complex process. Such examples relate to what historian Peter Stearns considers to be some of the distinctive concerns of social history: "its focus on popular belief systems, . . its attention to the variety of sources and artifacts that evidence those belief systems, and ... its interest in the interaction of mental attitudes and behavior." 49

At the same time, identifying the special fabric of issues in domestic relations law can free its history from an overdependence on overarching causal forces such as the market, urbanization, industrialization, and the rise of the welfare state. Obviously, each of these, at various points in the past, played a role in the creation of various titles of the law. An emphasis on the historical context does not deny the quasi-autonomy of legal rules, one of the most valuable insights of the critical legal studies movement. But it insists that histori$\mathrm{cal}$ analysis must relate those rules to the distinctive environment of a given era. Mere assertions of the long-term indeterminacy of the legal rules fail to explain fully the existence of conflicting legal consciousnesses and conflicting uses of the law at any particular time in the past. ${ }^{50} \mathrm{In}$ his recent assessment of the antebellum married women's property acts, Richard Chused has sketched the kind of multivarite contextual picture needed to understand legal change:

developments in the culture at large created a milieu sympathetic to changes in coverture law. Romantic notions of family formation and maintenance, introduction of industrial production, and increases in literacy and educational

49. Peter Stearns, Toward a Wider New Vision: Trends in Social History, in Kammen, supra note 40, at 51 . For a similar argument about the power of beliefs to mold family policy see John Demos, Child Abuse in Context: An Historian's Perspective, paper, Armington Seminar, Case Western Reserve University, Nov. 1979; for late nineteenth-century discussions of the suit see Recent Cases, 7 Harv. L. Rev. 372 (1894); James Schouler, Breach of Promise, 7 S.L. Rev. 65 (1881); J. Dundas White, Breach of Marriage Promise, 38 Law Q. Rev. 137 (1894).

50. For a contrasting approach see Frances E. Olsen, The Family and the Market: A Study of Ideology and Legal Reform, 96 Harv. L. Rev. 1497 (1983). For a similar critique of critical legal studies see Rayman Solomon, Transforming Political Disputes into Legal Questions: Administrative Appeals in the Seventh Circuit, 1920-1945, paper presented at the Law and Society Association annual meeting, June 9, 1985. And for an assessment of the implications of critical legal studies for historical analysis see Robert Gordon, Critical Legal Histories, 36 Stan. L. Rev. 57 (1984); Hendrik Hartog, Review Essay: The Politics of Law, 1984 A.B.F. Res. J. 851. 
goals for children gave women significant family roles. When distressed economic times appeared after 1839 , the moment was right for legislatures to codify a portion of the equitable separate estate tradition by insulating wives' property from their spouses' creditors. ${ }^{51}$

Failure to understand the historical context of domestic relations law has had its most debilitating impact in the creation of an assumed history of family law. That is, lawyers and others interested in family policy have often acted on assumptions about the past derived much more from popular belief than from historical inquiry. The breach of promise suit is particularly useful in making this point because it is now a prime example of the assumed history that haunts the introduction to topical sections of family law casebooks. The suit is treated as if it is, and thus always was, an anomalous action if not an anachronistic one. According to domestic relations casebook writer Homer Clark: "The action for breach of a promise to marry has become an anachronism in American law, perhaps because engagement is now recognized for what it should be, that is, a period of increased intimacy in which the parties can make the final decision whether to marry without worrying about the possibilities of a lawsuit if one of them should choose not to go through with the marriage." \$2 Yet, because the suit so easily fit into the nineteenth-century conception of domestic relations law, it underscores the changing context of American family law and suggests the contingent nature of legal definitions of engagements. In other words, the history of the breach of marriage-promise cases demonstrates that views of the family, past and present, are not ahistorical phenomena but products of their times. Courtship customs and morals have not had transcendent meanings, but have meant different things at different times to different people. Those differences, again past and present, had and have popular and professional implications.

Finally, legal historians may well need to devise generalizations about law and society that can accommodate the peculiarities and similarities of each area of law. The peculiar features of family law underlines the need to link it to other areas of the law in a way that can illuminate this category and the others. After all, assertions of distinctiveness can only be sustained through comparative analysis. Comparison can then produce a synthesis that will place legal development in a context that allows for variation according to legal category, class, race, and the other significant distinctions of nineteenth-century America. It is this kind of sociocultural dimension that the law of the family can bring to legal history.

\section{Institutional STRUGGLES AND Judicial AUTHORITY}

The creators of American domestic relations law are the next concern of this essay. A discussion of their role highlights the institutional context of the law of the family-one particularly important for family history. Three

51. Chused, supra note 46 , at 1361 .

52. Homer Clark, Domestic Relations: Cases and Problems 13 (2d ed. St. Paul, Minn., 1974); for a more historically nuanced account by Clark, see Law and Domestic Relations 1-3 (St. Paul, Minn., 1968). 
groups of institutional actors stand out as most significant in the legal debate over the family: appellate judges, state legislators, and family reformers. The specific titles of nineteenth-century family law emerged out of the conflicts and collaboration of these groups as they mediated questions raised by the law's users. Though judges, legislators, and reformers all shared in the creation of an American family law, their roles were not equal. Judges played the primary role. They became the main domestic relations agents of the expanding republican state. Consequently, the judiciary became the medium through which sociocultural factors like those discussed in the breach of marriage-promise cases were assimilated into domestic relations law.

Clarifying the judicial authorship of American domestic relations law is one contribution the legal history of the family can make to our understanding of the public environment of past households. Such a clarification is needed to link the past to the present public policy debate over the family. Though cases like Roe $v$. Wade impress on us all the contemporary role of the federal judiciary in family affairs, similar judicial activities in the past are generally unknown. Indeed, much present-day commentary by historians, lawyers, and social scientists is prefaced by assertions that contemporary judicial activity is unprecedented, thus freeing critics from the need to understand the past. For example, in The Willowbrook Wars, a recent study of the process of deinstitutionalization of mental patients in the $1960 \mathrm{~s}$, historians Sheila and David Rothman discovered the role of judicial instrumentalism in social policy. ${ }^{53}$ In this case, the courts initiated and supervised deinstitutionalization procedures. Lacking a social history of such judicial actions, David Rothman was led to conclude that the "first movement that really made use of the courts as a mechanism for change was obviously the civil rights movement." The judicial activity they chronicled, they assumed, was an outgrowth of civil rights litigation tactics and, thus, a completely new use of the bench. ${ }^{54}$ It is precisely such a misunderstood past that underscores the need to recover the institutional dimension of family history and the social dimension of legal history. As Ryan has argued, "[i]n the past as in the present, family members have repeatedly taken their grievances and their concerns into the streets and before government bodies."ss

Legal historians, of course, have created a significant body of work on judging; yet here again the emphasis has been on commercial law judging. The history of judges and social issues is unwritten. Moreover, the anti-court bias of the Hurst school of legal history-the oft-repeated legal realist admonition that law is more than what appellate courts say-has been carried to such an extreme by some of its devotees that we do not have a very com-

53. Sheila M. Rothman \& David J. Rothman, Willowbrook Wars: A Decade of Struggle for Social Justice (New York, 1984).

54. David Rothman is quoted in Jay Kaplan, Writing Contemporary History: Social Change, Jurisprudence, and the Uses of History: A Conversation with Sheila and David Rothman, Federation Rep., Nov./Dec. 1984, at 8. For another example of this point see Donald Horowitz, The Courts and Social Policy (Washington, 1977).

55. Ryan, supra note 6, at 191 . 
prehensive understanding of judicial history. ${ }^{56}$ Assessments of the role of the state appellate judiciary in the creation and elaboration of an American law of domestic relations can thus add a new perspective to legal and family history by outlining the role of a relatively unstudied actor.

However, a little background is needed. Judicial innovation in family law occurred, in part, because the revolutionary generation redefined the place of the law in America. As legal historians have argued with increasing clarity, the bench benefited immensely from a republican restructuring of the polity. The courts' new status as a coequal branch of government, the tacitly accepted power of judicial review, the wide degree of judicial freedom sanctioned by federalism, and the emergence of a franker style of judicial opinion writing converged to give judges policy-making powers denied their colonial ancestors and English brethren. Judicial power grew further as early nineteenth-century legislatures gradually relinquished authority over private legislation such as corporate charters and divorce, professionals dedicated to common law supremacy ousted lay judges, and judges wrested control of trials from juries.

Despite repeated complaints about the undemocratic nature, monopolistic practices, and class allegiances of the bench, a powerful judiciary profoundly affected political authority in the new Republic. In particular, it helped legitimate litigation as the society's primary institutional method of dispute settlement. By doing so, it fostered the legal order's own brand of policy making, one rooted in judicial and professional antistatism and common law chauvinism. Generally unhampered by weak state executives and part-time legislators, judges at all levels of government often became the most active agents of the state. They took the lead in devising and revising the law governing social and economic life from railroads to families. ${ }^{57}$

Equally important, judges assumed their new roles in ways that were more varied than those presented in legal historiography. In domestic relations they became a kind of state patriarch. Patriarchy has a broad range of meanings, yet it is the most evocative label for the nineteenth-century judicial approach to family law. The label is useful, in other words, because it suggests the way that judges themselves viewed their role in family legal disputes. The designation "judicial patriarchy" indicates that part of the consciousness of these men, and part of their power, stemmed from the ability of judges to divide the world into various categories and assume different poses in each; these ranged from patriarch to promoter to policeman. The work of legal his-

56. For Hurst's most recent statement on the issue see supra note 8, at 294-96.

57. Gordon Wood, The Creation of the American Republic, 1770-1787 (Chapel Hill, N.C., 1969); Eric Foner, Tom Paine and Revolutionary America (New York, 1976); Richard Ellis, The Jeffersonian Crisis: Courts and Politics in the Young Republic (New York, 1974), see esp. pt. 3. Horwitz, supra note 14; Lawrence M. Friedman, A History of American Law, at pt. 2 (New York, 1973); Mark DeWolfe Howe, The Creative Period in the Law of Massachusetts, 69 Proc. Mass. Hist. Soc'y 237 (1947-50). For a compelling assessment of the historiography of the period see Hendrik Hartog, ed., Law in the American Revolution and the Revolution in Law (New York, 1981), especially the concluding essay by Hartog, Distancing Oneself from the Eighteenth Century: A Commentary on the Changing Picture of American Legal History. 
torians like Leonard Levy on particular judges (such as Lemuel Shaw) and that of Harry Scheiber on particular judicial creations (such as eminent domain) have delineated some of these poses. ${ }^{58}$ Patriarchy helps locate another variant of judicial consciousness. This one was grounded in age and gender beliefs as well as in professional values, and it helped perpetuate paternal authority in republican domestic relations. Indeed, the judicial role in redefining the responsibilities of males for breaching a promise to wed is one example of this patriarchal role. ${ }^{59}$

\section{A National Marriage Law?}

The consistent failure to create a codified national family law offers one concrete example of the nature and implications of the "judicial patriarchy." An expression of the nation's persistent localism, opposition to national jurisdiction over the family, lay at the heart of nineteenth-century domestic relations law. It stemmed from the deep-seated republican aversion to centralized government in general and, more particularly, the lingering localist corollary that state policy makers and community officials best understood the dynamics of family life. Though resistance to federalizing efforts characterized many bodies of law in the era, it is the combination of distinctiveness and commonality between legal categories that this facet of nineteenth-century domestic relations law reveals; a combination vital to an understanding of the institutional context of the law of the family. The states tenaciously clung to their right to govern the home in the face of recurrent attempts at national uniformity. Overturning a writ of habeas corpus in an 1890 child custody dispute, United States Supreme Court Justice Samuel F. Miller declared unequivocally: "The whole subject of domestic relations of husband and wife, parent and child, belongs to the laws of the States and not the law of the United States." 60

State domestic relations chauvinism encouraged a reliance on the courts to harmonize the laws of the disparate members of the union, as was evident in the discussion of the shifting judicial treatment of seduction under the cover of a marriage promise. Common law doctrines arose out of conflicts between state family codes. Judicial solutions took two forms: a loosely arranged set of national domestic relations doctrines, such as those concerning common law marriage or the "best interest of the child," and a set of rules devised to

58. Levy, supra note 27; Harry N. Scheiber, The Road to Munn: Eminent Domain and the Concept of Public Purpose, 5 Persp. Am. Hist. 329 (1971).

59. For a more thorough discussion of this point see Michael Grossberg, Who Gets the Child? Custody, Guardianship, and the Rise of a Judicial Patriarchy in Nineteenth-Century America, 9 Feminist Stud. 235 (1983); and see Eileen Boris \& Peter Bardaglio, The Transformation of Patriarchy: The Historic Role of the State, in Irene Diamond, ed., Families, Politics, and Public Policy: A Feminist Dialogue on Women and the State 70 (New York, 1983); Gordon J. Schochet, Patriarchalism in Political Thought (New York, 1975); Janet Rifkin, Toward A Theory of Law and Patriarchy, 3 Harv. Women's L.J. 83 (1980); Paul Conner, Patriarchy: Old and New, 17 Am. Q. 48 (1965); Fliegelman, supra note 24.

60. In re Burrus, 136 U.S. 586, 593-99 (1890); and see Barber v. Barber, 63 U.S. 582 (1858); Thomas I. Cooley, Michigan: A History of Its Government 227-28 (2d ed. Boston, 1905); Note, Federal Jurisdiction of "Domestic Relations" Cases, 7 J. Fam. L. 309 (1967). 
settle jurisdictional disputes that fell within the legal category titled "conflicts of law." In either case, judges assumed a patriarchal stance by evaluating state legislation in terms of their perception of family needs, community interests, and national common law priorities.

Marriage law contains the most telling results. State legislators and judges created a morass of marriage regulations, some universal, others contradictory, and a few purely idiosyncratic. Disputes were inevitable. A pair denied the right to wed under one state's laws could easily evade them and marry in a more congenial commonwealth. The passing of time only increased the regulatory difficulties. Improved transportation, especially the railroad, enabled couples to flee inhospitable states just at the time that family historians tell us that romantic love and nuptial individualism undermined the legitimacy of public marriage controls. Runaway marriages became a lucrative business for local officials and clerics willing to ignore legal niceties such as parental consent. In matrimony, as in many legal affairs, Americans developed a penchant for "forum shopping." 61

The validity of these runaway marriages raised serious questions about the allocation of policy-making powers and regulatory priorities within nineteenth-century domestic relations law. The first significant statement to address the larger legal implications of runaway marriages came in an 1819 Massachusetts decision. Medway v. Needham began when two paupers, a male mulatto and a white female, evaded the Bay State ban on interracial marriages and wed in Rhode Island. The towns of Medway and Needham later clashed when the wife attempted to transfer her domicile so she could collect poor relief in her husband's town. Chief Justice Isaac Parker readily acknowledged that the union would have been void had it been solemnized in Massachusetts. He also took note of doctrines of the law of nations that allowed countries to refuse to accept marriages of their citizens entered into outside their borders. ${ }^{62}$

These Continental rules served as the major legal guides to the issue. In chauvinistic early modern Europe, a Roman Catholic tradition that assumed the existence of roughly similar conceptions of marriages and nuptial regulations between countries had fallen before religious schism and political nationalism. Ulric Huber, a seventeenth-century Dutch legal scholar and widely recognized authority on the law of nations, offered a compelling solution. He advised that the principles of international comity did not require a country to accept marriages in violation of its own laws. Most European nations embraced this nationalistic doctrine and applied it when evading couples transgressed serious nuptial prohibitions. ${ }^{63}$

61. See, e.g., 2 James Kent, Commentaries on American Law 92 (4 vols. New York, 1826-1830); Andrews v. Herroit, 4 Cow. 510-31 (N.Y. 1825).

62. Medway v. Needham, 16 Mass. 157 (1819).

63. For a general discussion of these doctrines see David Engdahl, Full Faith and Credit in Merrie Olde England: New Insight for Marriage Conflicts Law from the Thirteenth Century, 5 Val. U.L. Rev. 1 (1970); id., Proposals for a Benign Revolution in Marriage Law and Marriage Conflicts Law, 55 Ia. L. Rev. 55, 58-116 (1969); Paul Finkelman, An Imperfect Union: Slavery, Federalism, and Comity 13-14 (Chapel Hill, N.C. 1981). 
In upholding the wife's claim, Parker wove the Continental rule into American common law in a judicial decision befitting the label "instrumental" that countless legal historians have applied to the period's judicial style. The chief justice balanced the usefulness of enforcing the ban on interracial marriages against the effects of dissolving consummated unions, and he recommended that state officials voluntarily accept marriages entered into legally in another jurisdiction. He urged that matrimony be made a general exception to the contractual rule invalidating agreements in fraudulent evasion of state law. "The exception in favour of marriages so contracted," Parker explained, "must be founded on principles of policy, with a view to prevent the disastrous consequences to the issue of such marriages, as well as to avoid the public mischief, which would result from the loose state in which people so situated would live." He demanded that states defer to a transcendent individual right, the decision to marry, and to his judicial determination that accepting runaway marriages better served the public weal than did strict enforcement. ${ }^{64}$ Decisions like this exemplify the nineteenth-century bench's balancing of social and legal interests in domestic relations law. And in cases like Medway v. Needham the judiciary supplied the initial solutions to runaway marriages and through them framed the debate.

Another Massachusetts judge, Supreme Court Justice Joseph Story, offered a more comprehensive solution in the first Anglo-American treatise on the conflicts of law, as international and interstate jurisdictional disputes came to be labeled. His 1834 tome represented a major conceptual transition. Story introduced the argument that differing national laws resulted from alternative policy demands instead of from misconstructions of universal rules. ${ }^{65}$ In his analysis of this development, Horwitz stresses the commercial implications of the new approach, particularly its compatibility with the aims of a judiciary intent on creating national market rules that favored enterprising entrepreneurs. ${ }^{66}$ In marriage, conflicts of law doctrines performed similar functions, but they also had a distinctive meaning. Determining the meaning of common impulses like these, which cut across legal categories, requires a broader context than entrepreneurial self-interest. Specifically, matrimonial decisions reveal a judicial determination to balance sectional nuptial customs with a lawyerly interest in creating national common law rules.

In this vein, Story placated minority and majority marriage policies by arguing that most marriages should be considered as valid by lex loci contractus [the law of the place where celebrated]. He insisted that "by observing this

64. Medway v. Needham, 16 Mass. 157, 160-61 (1819); and see West Cambridge v. Lexington, 18 Mass. (1 Pick.) 506 (1809); Putnam v. Putnam, 25 Mass. (8 Pick) 433 (1829).

65. Joseph Story, Commentaries on the Conflicts of Law (Boston, 1834).

66. Horwitz explained the nature of these changes in his study of commercial law: the shift to a conflicts approach reflected the erosion of the orthodox view that, since judicial decisions were mere "evidence" of a "true" legal rule, a conflict of decisions inevitably meant that one of these rules was simply mistaken. The field of conflicts of law, then, arose to express the novel view that incompatible legal rules could be traced to differing social policies and that the problem of resolving legal conflicts could not be solved by assuming the existence of only one correct rule from which all deviation represented simple error. Supra note 14 , at 246. 
rule few, if any, inconveniences can arise. By disregarding it, infinite mischief must ensue." ${ }^{67}$ Despite the restrictive use of the doctrine by the English and other Europeans, Story insisted that in the sprawling American Republic, social welfare tipped the scales of justice in favor of accepting most runaway marriages. Such a policy, he contended, was far better than "introducing distinctions as to the designs, objects, and motives of the parties to shake the general confidence in such marriages, and to subject the innocent issue to constant doubts as to their own legitimacy, and to leave the parties themselves adrift from their solemn obligations when they may become discontented with their lot." ${ }^{68}$ Story defended his presentation of the judicial solution to runaway marriages with precisely the same arguments used to uphold common law marriages and other individualistic legal doctrines that supported existing unions at the expense of statutory controls. ${ }^{69}$

Significantly, though, the justice cast this judicial solution in the congenial nineteenth-century language of states' rights. He called for what amounted to a territorial approach by urging that evasive marriages be recognized not because of their intrinsic legitimacy but out of compelling social imperatives. Story recognized that except for minimal constitutional constraints, republican federalism freed the members of the American union from acquiescing in the marital rulings and laws of other states. Thus, he assuaged state chauvinism by insisting that the decision to uphold a runaway marriage did not diminish a state's nuptial sovereignty; it merely placed a voluntary limit on those powers.

Story's nuptial rule represented far more than a politically expedient legal device. It provided the only semblance of coherence possible in this explosive topic by papering over inconsistent state laws with a rule that accepted their continued existence but provided a mechanism for resolving individual problems. The new doctrine thus accepted the legitimacy of state domestic relations jurisdiction and yet constituted an attempt to create a national common law by balancing centralism and localism. ${ }^{70}$

Most important, in this, as in much of nineteenth-century law, judges and their treatise-writing allies achieved those ends by elevating individual rights over state regulatory acts, relying on persuasion rather than compulsion in the regulation of legal behavior, and creating flexible doctrines dependent on judicial discretion. Indeed, these characteristics of the judicial solutions to domestic relations controversies may have been a part of the courts' attrac-

67. Story, supra note 65 , at 117.

68. Id. at 96 .

69. Joseph Story, Conflicts of Law 232-33 (3d ed. 1846); for the English rejection of Story's views see Brook v. Brook, 9 H.L. 193, 217-20 (1861); Anthony J. Bland, The Family and the Conflicts of Law, in Ronald Graveson \& F. R. Crane, eds., A Century of Family Law 274-80 (Cambridge, England, 1957).

70. For general discussion of the issue see Ernest G. Lorenzen, Story's Commentaries on the Conflicts of Law-One Hundred Years Later, 48 Harv. L. Rev. 15-21 (1934); Ernest G. Lorenzen \& Kurt Nadleman, Justice Story's Contribution to American Conflicts of Law: A Comment, 5 Am. J. Legal Hist. 230 (1961); Harold Horowitz, Historical Note: Choice of Law Decisions Involving Slavery: Interest Analysis in the Early Nineteenth Century, 17 U.C.L.A. L. Rev. 587-601 (1970); Note, American Slavery and Conflicts of Law, 71 Colum. L. Rev. 74 (1971); Finkelman, supra note 63. 
tiveness. Under judicial direction, family law could be perceived as essentially facilitative; that is, it seemed to let individuals structure their lives as they desired while reserving the courtroom as the forum for dispute resolution. ${ }^{71}$ What is more, such domestic relations doctrines allowed a judge to cloak himself in the guise of a patriarch watching out for his brood.

Born amid vicious sectional strife, the territorial approach to nuptial evasions remained virtually unchallenged in the decentralized American federation until late in the century. It proved so compelling that legislators and judges almost turned evasion into a marital right. They did so in disputes that involved regulations enacted by a minority of states. The most litigated issues were bans on the remarriage of divorced persons; affinal, consanguineous, and interracial restrictions; and statutes demanding nuptial forms such as licenses. Story's rules directed the courts to use discretion in balancing the claims of the partners to these unions with the nuptial directives of legislators.

State judges generally followed Justice Story's advice. They rarely invoked the state's sovereign authority to nullify out-of-state unions. Only couples who crossed the color line faced a consistently hostile judiciary. ${ }^{72}$ The rest of the judicial record is murky. However, the vast majority of out-of-state marriages apparently won legal recognition when challenged in civil or criminal proceedings. ${ }^{73}$ An 1899 Ohio decision, Courtright v. Courtright, expressed

71. For a discussion of the facilitating role of family law see Carol Weisbrod, Family, Church, and State, paper presented at the History of the Law of the Family Conference, School of Law, University of Wisconsin, July 1984, at 17.

72. The question of race was not an idle one. Flight became one of the few effective means of escaping the ban on interracial marriage. Couples returning home pitted the commitment of their states to a peculiar nuptial policy against the power of prevailing marital policy. Racism won out and thereby suggests that family law offers another vantage point from which to assess this fundamental American prejudice. In 1872, for example, the Tennessee Supreme Court defended the judicial power to nullify these marriages. The decision tapped the deep jurisdictional protectionism that Story had pacified but that miscegenation unleashed: "each state is a sovereign, a government within, of and for itself, with the inherent and reserved right to declare and maintain its own political economy for the good of its citizens, and cannot be subjected to the recognition of a fact or act contravening its public policy and against good morals, as lawful because it was made or existed in a state having no prohibition or even permitting it." Seventeen years later the same court distinguished its rulings from Parker's Medway decision by dismissing the earlier case as a mere political expedient in a state with so few blacks that it could have no harmful effect. Relying on flexible conflicts of law rules, courts in regions intent on using the law to separate the races came to the conclusion that interracial marriages so seriously threatened public welfare that they always had to be repressed. State v. Bell, 66 Tenn. (7 Baxter) 9, 10-11 (1872); Pennegar and Haney v. State, 87 Tenn. 244 (1889); and see Dupre v. Boulard, 10 La. Ann. 411 (1855); Kinney v. Commonwealth, 71 Va. (30 Gratt.) 856 (1878); State v. Tutty, 41 F. 753 (1890); Succession of Caballero, 24 La. Ann. 573 (1872); Gilbert Stephenson, Race Distinctions in American Law 93-95 (New York, 1910). The color line was erased only in some cases of native American/white marriages; see Note, Legal Status of Indian Marriage, 13 Yale L.J. 250-52 (1904); Note, Indian Marriages and Inheritance, 24 Am. L. Rev. 149-51 (1890); Maxwell Bloomfield, American Lawyers in a Changing Society 111-12 (Cambridge, Mass., 1976).

73. By decreeing that marriages should be governed by the law of the place of celebration, the courts denied extraterritorial authority to most legislative regulations. Applying its own amorphous brand of uniformity, the judiciary and legislative codifiers and treatise-writing collaborators amalgamated private rights, state regulatory sovereignty, and judicial oversight. Yet even this semblance of doctrinal coherence became possible only by constructing a broad base for the conflicts of law. For examples of the judicial treatment of these unions see Barney v. Cuness, 68 Vt. 51 (1895); Houston v. Duker, $86 \mathrm{Ky} .122$ (1887); Dannelli v. Danelli, 67 Ky. (4 Bush.) 51 (1868); Harrison v. State, 22 Md. 468 (1864); Blaisdell v. Blickum, 139 Mass. 250 (1885); Loring v. Thorndike, 5 Allen 174 (Mass. 1862); O'Neal's Case, 58 Va. (17 Gratt.) 
prevailing judicial sentiments. ${ }^{74}$ The court faced a dispute over a woman's estate between her husband and brother. The late wife had wed despite being below Ohio's statutory nuptial age and having failed to secure her parent's consent. She had circumvented the law by fleeing to neighboring Kentucky. Shortly before her sixteenth birthday, the star-crossed bride had died. The state bench rejected her brother's contentions that her nuptial violations nullified the union. Ohio's laws, the justices asserted, "only profess to regulate marriage in Ohio." They did not "profess to any extraterritorial operation to their provisions or principles with respect to citizens of this state nor do they attempt to prevent or prohibit our citizens from going elsewhere to celebrate marriage, much less declare such marriages void."75

\section{Competing Lawmakers}

Late in the nineteenth century, though, a chorus of complaints arose against the conflicts of law. Self-styled family savers led these choirs of social reformers. A sense of family declension propelled legions of monitors of the hearth into action. The progenitors of an increasingly sophisticated and varied line of reformers that would stretch well into the twentieth century, family savers sought to save the home and thus the Republic by turning their family ideals into a set of unbreakable commands. A diverse lot, family reformers included patricians, social-purity advocates, clerical crusaders, feminists, medical and legal professionals, and a host of others. They were often at odds with each other in diagnosis and cure. They united, though, in a determination to save the family as they then defined it. This reform movement took place at precisely the same time that other changes of the era, such as the rapid rise in the factory work force, growth of industrial cities, and massive waves of immigrations, added new strains to family life and new variety to family forms. Most important here, family savers competed with the bench as policy makers. They helped alter the law's discourse by demanding that the focus of the law be shifted from the promotion of individual rights to the enhancement of state responsibility for the family. By doing so, reformers forced a reevaluation of domestic relations law that challenged numerous judicial creations and threatened judicial domestic relations authority. ${ }^{76}$

582 (1867); Bird's Case, 62 Va. (21 Gratt.) 86 (1872); Jones v. Reddick, 79 N.C. 290 (1878); Clark v. Clark, 52 N.J. Eq. 650 (1894); People v. Ines, 110 Mich. 520 (1896); People v. Loomis, 177 Ill. 219 (1898); Walker v. Potilla, 75 Tenn. 448 (1881); Moore v. Hegeman, 92 N.Y. 521 (1883); State v. Shattuck, 69 Vt. 403 (1897); David Stewart, A Divorced Person's Right and Capacity to Marry, 20 Am. L. Rev. 718-26(1880); J. N. Brodie-Innes, Some Curiosities of International Marriage Law, 13 Ill. L. Rev. 184 (1918-19); Charles W. Taintor III, Effects of Extra-State Marriage Ceremonies, 10 Miss. L.J. 105 (1938).

74. 11 Ohio Dec. 413, 414 (1899).

75. Id. at 414 .

76. For discussions of family saving see Ronald Walters, The Family and Ante-Bellum Reform: An Interpretation, 3 Societas 221 (1973); William Leach, True Love and Perfect Union: The Feminist Reform of Sex and Society (New York, 1980); John Demos, Images of the Family, Then and Now, in Virginia Tuft \& Barbara Myerhoff, eds., Changing Images of the Family 49-55 (New Haven, Conn., 1979); Paul Boyer, Urban Masses and Moral Order in America, 1820-1920, at 18-120 (Cambridge, Mass., 1978); W. Norton Grubb \& Marvin Lazerson, Broken Promises: How Americans Fail Their Children 11-40 (New York, 1982). 
Nuptial conflicts of law offer one example of this new debate. Family savers accused the law's nuptial doctrines of making evasion easy, in fact of rewarding it, and thus rendering needed state regulations impotent and undermining the home. Charles Noble began an 1881 prize-winning essay at New York University Law School by explaining that his purpose in writing about marriage and divorce law was to "set forth, in the simplest way, the startling diversity, the appalling conflict of the laws which regulate the vital and fundamental relations of the family and the state in a nation of fifty million." Family bristled with indignation at the interstate laxity of marriage regulation. Its 1907 survey of marriage and divorce disclosed that the illicit New England highway first uncovered in the Medway decision still flowed with traffic: "No less than 523 couples who were residents of Massachusetts took out marriage licenses in the city of Providence alone in the year of 1906." The League's director, the Reverend Samuel Dike, complained of the growth of "a serious evil from the practice of parties going to a state other than their own to be married, either more hastily or more secretly, or for some other trivial reason." 78

Critics like these assigned primary responsibility for the confused and dangerous condition of marriage law to the nuptial individualism and undue deference to states' rights sanctioned by conflicts of law rules. According to one attorney, state "pride and patriotism almost make it a point of honor that each local legislature, in all conceivable subjects, should have a policy of its own, and not tamely reproduce the enactments of other communities." "79 $\mathrm{Re}-$ formers called for uniform national laws. Since the long-standing denial of federal jurisdiction over domestic relations blocked unilateral congressional action, reformers had two options. They could secure passage of a constitutional amendment conferring nuptial authority on the national legislature, or they could press for state lawmakers to enact complementary nuptial statutes.

Both approaches were pursued because reformers themselves differed in their commitment to state domestic relations sovereignty. Some demanded that the states cede that authority, others that the states voluntarily accept uniformity. Neither effort met with great success. Reformers bombarded Congress with petitions for a constitutional amendment 33 times from 1884 to 1914. None passed. Reformers working in the states fared little better. Their drive to eliminate localism from marriage law became a division of the campaign to tighten nuptial controls and a companion piece to the effort to limit out-of-state divorces. Model statutes, support from organizations such as the American Bar Association and the League for the Protection of the Family, and persistent lobbying all failed. A special committee of the Na-

77. Charles Noble, The Law of Marriage and Divorce 1 (New York, 1882).

78. League for the Protection of the Family, 1907 Annual Report 7 (Boston, 1908).

79. Edward Stanwood, National Jurisdiction Over Marriage and Divorce as Affecting Polygamy in Utah, 2 Andover Rev. 70 (1884); and see William L. Snyder, The Geography of Marriage (New York, 1899); Charles Stuart Welles, The Apotheosis of Christ, or, the New Marriage (New York, 1884). 
tional Conference of Commissioners on Uniform State Laws reported in 1916 that "the subject of marriage and divorce is in many of the states considered to be strictly a local question." ${ }^{80}$ Instead the movement had come to be seen as a direct challenge to state sovereignty in domestic relations, what law professor and Progressive reformer Ernst Freund called the "most determined local policies." 81

As Story had shrewdly perceived, conflict of law rules that genuflected to state sovereignty had produced the only national family law possible in nineteenth-century America: a complex batter of dominant common law doctrines and statutory policies leavened by local initiatives. The failure of the drive for uniform marriage laws does not indicate a deference or submission to judicial authority as much as it demonstrates the continued saliency of the judicial approach. And it suggests that part of the courts' power lay in their ability to use doctrine to structure debate.

\section{Historiographical Consequences}

The persistence of antebellum judicial solutions to the vexing conflicts of law regarding runaway marriages uncovers a critical element of the institutional context of nineteenth-century domestic relations law. It indicates how a merger of legal and family history can add a new dimension to our understanding of legal and family change, one related to an understanding of the role of sociocultural concerns in the law of the family but distinct from it. Beyond the points made above, three other conclusions should be noted.

First, the legal debate over runaway marriages has implications for the social history of reform, a body of scholarship relied on by historians as well as by contemporary policy makers on occasion. Studies of social reform generally fail to recognize (let alone understand) the role of legal institutions and actors in devising and applying reforms. Instead, nineteenth-century critics of social ills-the family savers, for example-figure almost exclusively as the actors in the history of reform efforts, including studies that deal with family law topics such as divorce and juvenile deliquency. O'Neill, for instance, depicts the failure of the uniform divorce law movement as one more example of reformist misconception. He argues that the movement was doomed to fail because reformers did not understand the new personal nature of matrimony as a private relationship based on affection and personal choice. Consequently, O'Neill claims, reformers proposed statutory solutions that could not counter this private nuptial reality. But by failing to examine the legal aspects of the subject, he misunderstood the full context of the issue. ${ }^{82}$

80. Commissioners quoted in O'Neill, supra note 2, at 248, and see generally 238-53; and see History of Efforts to Secure a Uniform Law on Marriage and Divorce, 6 Congressional Digest 183 (1927); Amasa E. Eaton, Proposed Reform in Marriage and Divorce Laws, 4 Colum. L. Rev. 243 (1904); Mary Richmond \& Fred S. Hall, Marriage and the State 188-206 (New York, 1929); 1 Chester Vernier, American Family Laws 183-209 (4 vols. Stanford, Cal. 1937-38).

81. Freund, Uniform Marriage and Divorce Legislation, 21 Case \& Com. 7 (1914-15).

82. O'Neill, supra note 2, at 238-53. 
A legal perspective suggests another interpretation of the failure to pass national divorce reforms. The legal culture of Progressive America may well have contained institutional and political factors that made uniform national policies impossible to achieve in a number of social and commercial areas. Historians such as Morton Keller and Melvin Urofsky have stressed the vagaries of state judicial decisions and legislative enactments in the era-diversity remained the rule in policies on everything from matrimony to incorporation. ${ }^{83}$ As a result, no single policy tradition existed in the nation, and reformers had to wage state-by-state battles. Consequently, as did matrimony, each issue raised a combination of distinct and common concerns-a situation that led historian William Graebner to argue in a structural and interestgroup analysis of the issue that the possibilities of success in obtaining uniform policies varied by issue: less success for minimum-wage legislation for women and children because of fundamental conflicts among workers, organized labor, social reformers, and entrepreneurs; greater success in workman's compensation because of seeming agreement among the various interested parties. Even so, as he documents, divergent state policies flourished under the compensation laws. Though the uniform law movement suffered from structural and organizational flaws and competing state interests, its appeal to Progressives, Graebner argues, lay in its occupation of "a middle ground" as a "device that would take a variety of questions beyond the states but keep them from the national government." 84 Thus, the inability of reformers to enact uniform nuptial laws not only illustrates why the nineteenth-century judicial solution to runaway marriages continued to be attractive but also illustrates an institutional reality as important in stymieing reform as were nuptial beliefs.

Similarly, the judicial role in formation and implementation of social reforms has been ignored. In his analysis of antiabortion legislation, for example, James Mohr stresses the primacy of professionalizing doctors in the midnineteenth-century passage of bans on abortion..$^{85} \mathrm{He}$ argues that the demand of physicians for control of all aspects of medical practice led them to mount a national campaign against abortion. Yet Mohr never directly addresses the manner in which judicial doctrines, such as "quickening," dictated reform demands, legislative solutions, and enforcement practices just as did judicial rules on runaway marriages. That is, judges used the traditional notion of quickening, the assumption that initial movements in the womb indicated that fetal life had begun, first to establish a common law rule that no crime occurred before quickening and then to interpret statutes in ways that limited prosecutorial success by demanding proof of fetal anima-

83. Morton Keller, Affairs of State 407-8 (Cambridge, Mass., 1977); Melvin I. Urofsky, State Courts and Protective Legislation During the Progressive Era: A Reevaluation, 72 J. Am. Hist. 63 (1985).

84. William Graebner, Federalism in the Progressive Era: A Structural Interpretation of Reform, $64 \mathrm{~J}$. Am. Hist. 345, at 345, and see 351-54 (1977).

85. Mohr's discussion of abortion law can be found in Abortion in America chs. 5, 8-9 (New York, 1978). 
tion for a conviction. ${ }^{86}$ The statutes themselves often codified judicial decisions and were dependent on judicial interpretation. Indeed, judicial and bar resistance to the antiabortion campaign figured prominently in the charges of physicians against lawyers. Overlooked in studies like Mohr's, which examine the external but not the internal workings of the law, is the consistent reality that debate often took place within a discourse established by judges like Parker and Story. It is this kind of perspective, in this case the power of judicial language to establish the definition of problems, that a merger of family and legal history can provide.

In a related way, the institutional dimension evident in the debate over runaway marriages reinforces the growing critique of monolithic theories of social control. Such explanations of the content and application of social policy, most dogmatically asserted in the work of such social scientists as Anthony Platt, who argues that the juvenile court must be understood only as a mechanism of class oppression, dominate the institutional historiography of the nineteenth century. ${ }^{87}$ These arguments assume the existence of a monolithic state and uniform conceptions of governance that allowed reformers to use public and private agencies to impose their values and goals on the society. Yet such versions of reform are at odds with the diversity of the nineteenth-century polity. For example, contentions like Platt's that juvenile courts were created primarily to enforce an elite social agenda ignore the emergence of a tradition of turning over family dispute settlement to the bench. That institutional tradition also played a role in the creation and structure of juvenile courts by encouraging the use of courts as the proper medium for reforming the young. The tradition itself was a product of the judicial patriarchalism discussed here and evident in the analysis of seduction as well as in the creation by the courts of rules like the "best interest of the child" doctrine in custody disputes or feminine-biased definitions of mental cruelty in divorce proceedings. ${ }^{88}$

Though they supplied a needed revision of an earlier historiography that uncritically accepted the benevolent intentions of reformers, social-control arguments have become as stultifying as the work they sought to replace. At the same time a new wave of revisionism provides little support for a return to a conflict-free-consensus view of the past evident in the social history of Oscar Handlin and the legal history of Hurst. In both these genres, assumptions about cultural uniformity and shared national values blinded historians

86. For a more thorough discussion of this point see Grossberg, supra note 18 , at ch. 5 .

87. Anthony Platt, The Child Savers (Chicago, 1969), and see the introduction to the revised edition of 1977.

88. For the relationship of juvenile justice and judicial patriarchy see Grossberg, supra note 18, at 279, 303-4. See also William Muraskin, The Social Control Theory in American History: A Critique, 9 J. Soc. Hist. 559 (1976); Gareth Stedman Jones, Class Expression v. Social Control, 4 Hist. Workshop, 163 (1977); Gerald Grob, Reflections on the History of Social Policy in America, 1979 Rev. Am. Hist. 294; Walter Trattner, ed., Social Welfare or Social Control (New York, 1982); Michael B. Katz, Poverty and Policy in American History 185-222 (New York, 1983); Grubb \& Lazerson, supra note 76, at 115-26; Matthews, supra note 19 , at 101-4, 112-13. 
to significant differences between classes, races, and regions. ${ }^{89}$ Instead, revisionist legal and social history is beginning to offer evidence for a middle ground between elite hegemony and an all encompassing set of shared national values. Conflicts over runaway marriages are a case in point. They highlight the manner in which professional values and the partial autonomy of legal rules enabled various authors of domestic relations law to evade, adapt, or dispute elite reformers' efforts to impose their matrimonial preferences on the citizenry. Reformers' failure to abolish common law marriages through statutory bans is another case in point. Domestic relations law suggests that an unsteady mixture of cooperation, conflict, assertions of institutional allegiances, and strains of class solidarity characterized the nineteenthcentury polity. The debate over social control has clouded such issues. Its revision indicates that assumptions about institutional actors need much further study.

Second, the debate over runaway marriages illuminates another broad question in legal and family history: the issue of public and private domains within nineteenth-century American thought and practice. The very notion of public and private spheres and the concrete entities they purport to represent have been challenged by both family and legal historians. Increasingly family historians have questioned the notion of a rigid separation between the family and the larger society as depicted in nineteenth-century conceptions of the home as a refuge. Ryan argues that "[u]nder sustained scrutiny the boundaries between the family and society, the last cherished symbol of American domestic ideology, seem to shift and shimmer and dance before the historian's eyes, until the image of the family itself becomes blurred."90 Yet Ryan does acknowledge the potency of the image of the home as refuge from a competitive world in nineteenth-century domestic ideology even if it broke down in practice. Similar points have been made about the division into public and private spheres of the construct called the legal system..$^{91}$

A history of nineteenth-century domestic relations law can contribute to that debate by providing a set of examples of how one group of actors, the appellate judiciary, conceived of and acted on the belief that public and private spheres not only existed but had to be protected. Much of the bench's patriarchal conception of its role stemmed from the widely held belief that the two domains existed and that the place of the family lay in the private

89. For Hurst's most recent defense of consensus legal history see supra note 8, at 297-305. Consensus is used to label a school of historians like Handlin, Hurst, Louis Hartz, and Daniel Boorstin, who wrote in the post-World War II era. Their analyses abandoned the conflict models of earlier historians like Charles Beard in favor of one that viewed American society as stable and homogeneous. They stressed political and economic consensus and agreement as the major poles of the American past, particularly liberal political principles such as the right to own private property, limited government, and natural law.

90. Ryan, supra note 5 , at 190 , and see $186-89$.

91. For a view different from Ryan's see Barbara Laslett, The Family as a Public and Private Institution: An Historical Perspective, 35 J. Marriage \& Fam, 480 (1973). The debate in legal history is exemplified by the debate in a forum on the question published in volume 130 of the University of Pennsylvania Law Review (1982); see especially Duncan Kennedy, The Stages of the Decline of the Public/Private Distinction; Morton Horwitz, The History of the Public/Private Distinction; and Robert Mnookin, The Public/Private Dichotomy: Political Disagreement and Academic Reputation. 
realm. Judges assumed a role as paternal umpires resolving inevitable domestic disputes. Judicial power rested in part on the ability of judges to redefine the shifting boundaries between the family and the state that they had taken a leading role in staking out early in the century.

It was in this way that the ideal of family autonomy could be maintained. The family was private as long as public expectations were met or deviance was not brought to public attention; when either occurred, latent state authority could be exercised. Even Hurst has acknowledged that "nineteenthcentury courts predominated in structuring private relationships, as through the law of contract and property." "92 Their power to do so in family law, and in many other areas of social and economic life, is an apt example of what the political scientist Stephen Skowronek has termed the nineteenth-century "state of courts and parties." In that peculiar republican polity, he argues, "[t]he judiciary not only helped define the terms of internal governmental activity, it also helped define relations between state and society. It fell to the courts at each level of government to nurture, protect, interpret, and invoke the state's prerogatives over economy and society as expressed in law." Complementing that perception of judicial responsibility was the existence of a type of deferential legislative behavior in intractable issues that historian Stanley Kutler has termed "legislative acquiesence."

Finally, the debate over nuptial conflicts of law raises questions about the sources of a legal history of the family drawn from a merger of legal and family history. The history of domestic relations law in this essay comes primarily from a study of legal doctrine. Doctrinal history is a common yet controversial form of legal history. Its source materials are appellate cases, which are generally cast as liabilities because of their unrepresentativeness, problematic impact, and contingent meaning. These liabilities have been raised repeatedly and are perhaps expressed most directly in the legal realist distinction between law on the books and law in action. Due to these critiques, doctrinal history has been classified, particularly by legal historians captured by the social science quest for scientific objectivity, as traditional and tainted. Even so, the current struggles on law faculties between critical legal studies advocates and liberal social scientists, in which the former champion a view of doctrine as indeterminate, quasi-autonomous and, thus, evidence of judicial choice rather than of professional logic or social necessity, suggests a revival of interest in doctrinal study. However, the implications of these controversies for historical analysis remain unclear. ${ }^{95}$

92. Hurst, supra note 8 , at 295.

93. Stephen Skowronek, Building A New American State: The Expansion of National Administrative Capacities, 1877-1920, at 27 (New York 1982); and see Elizabeth Mensch, The History of Mainstream Legal Thought, in David Kairys, ed., The Politics of Law 24 (New York, 1982).

94. Stanley Kutler, Labor, the Clayton Act, and the Supreme Court, 3 Lab. Hist. 19 (1962).

95. For a discussion of these issues see G. Edward White, The Appellate Court Opinion as Historical Source Material, 1 J. Interdisciplinary Hist. 491 (1971); Robert A. Kagan et al., The Business of State Supreme Courts, 1870-1970, 30 Stan. L. Rev. 121 (1977); Hurst, supra note 8, at 294-97; Gordon, supra note 50 . 
Interestingly, the oft-stated deficiencies of doctrine as sources are akin in some ways to problems confronting family historians who rely on diaries, advice books, letters, and other formal statements on family affairs for qualitative assessments of past households. These sources too stand accused of elitism, bias, and unrepresentativeness in a research field dominated by quantitative analyses of demographic phenomena like fertility, marital age, and occupational mobility patterns. And a revival of interest in qualitative sources for family history parallels to some degree the law school debate, though the types of sources should not be confused or even all lumped together in dismissive categories. In both cases, seemingly objective data have been shown to be both biased in their own way and limited in terms of the questions they can answer. ${ }^{96}$

In domestic relations law the limitations of doctrinal history are real enough. Doctrinal records deal with only a fraction of families and they translate family life into the peculiarities of the legal process. They cannot be used to depict the internal reality of past households nor can their impact on domestic life be assumed. But the possibilities outweigh the difficulties. In fact, the institutional origins and use of legal rules differentiate them from sources like letters and diaries and make them an invaluable resource for merging family and legal history.

More directly, the forms, decisions, statutes, and practices that came to constitute nineteenth-century domestic relations law comprise both a record of critical past disputes and a set of changing resolutions; that is, an arena of controversy that can be examined to locate the past relationship between the home and the law. The historical value of doctrine, then, is not that it reveals the hornbook law on a domestic relations topic in a given year, but that it represents important attempts to articulate an American law of the family. In addition, doctrinal rules are the recorded statements of institutions and individuals that appear to have had a profound impact on the way other Americans conceived of the family and the law. Judicial creations such as nuptial conflict of law rules and the quickening doctrine in abortion, for instance, helped frame the era's discourse on matrimonial regulation and abortion policy in popular magazines, religious periodicals, professional journals, and newspaper editorials as well as in courtrooms and State Houses. That is, time and time again, judicial doctrines were used as a basis of debate and, thus, as solutions allowing the bench extraordinary power over popular and professional conceptions of domestic relations. The judicial use of the lex loci rule in matrimonial conflicts of law litigation is but one example. It dictated both the conception of runaway marriages in the popular and professional mind and the nature of reform. The judicially created rules governing breach of marriage promises did the same. When combined with the findings of family and legal historians, judicial doctrines such as these are one window on the 
world of nineteenth-century Americans. They allow us to view many of the issues, struggles, and assumptions that drew families into the legal system.

Far from being marginal to the legal history of the past, as social scientific legal historians have argued, doctrine indicates that legal rules often defined judicial roles and structured professional and popular debate. Indeed, domestic relations law demonstrates the need to reaffirm that legal rules are central to the study of nineteenth-century legal history despite the limitations of doctrine as evidence. Even Hurst, the most dogmatic critic of doctrinal history, has acknowledged that from about 1810 to 1890 " judge-made (common) law provided a great bulk of standards and rules for market operations (in the law of property, contract, and security for debt), for domestic relations, and for defining familiar crimes against persons and property." research goal should be to link the work of appellate courts with lower courts, legislatures, administrative bureaus, and other institutions rather than to perpetuate arid debates over their limitations.

The resurrection of doctrinal history is all the more necessary because few historians understand the way courts work. In his study of nineteenth-century juvenile justice, for example, historian Steven Schlossman introduces his topic with a brief doctrinal history and the easy conclusion that "the judiciary simply gave legal expression to . . . conventional beliefs." He then asserts that it is necessary to comprehend "the law of juvenile justice more in terms of conscious social policy than obscure legal precedents." That dismissal then allows him to study juvenile justice by paying "scant attention to juvenile law, and instead concentrate on vibrant social forces, ideologies, institutional designs, and pedagogical theories which more directly shaped our correctional past." ${ }^{98}$ Doctrinal history points up the problems of such a method; it can thus open up new vistas on the history of the law of family and suggest interconnections between levels of the legal order and between the legal order and the larger society.

\section{The Changing Periods of Nineteenth-Century Family Law}

Periodization is the final theme of this essay. Breaking the past into various time frames and locating the distinctiveness of each allows a historian to mold chronologically related phenomena into a comprehensible whole by identifying continuities and change-the issues at the heart of historical interpretation. But periodization raises issues beyond those of historical analysis. As historian Peter Stearns has observed, periodization is "the essential contribution of historians to the understanding of change." "B9 By delineating examples of chronologically related changes historians can aid others interested in family policy in understanding the emergence and decline of an era's climate of opinion and action. In that vein, existing periodization schemes in

97. Supra note 8, at 294.

98. Steven Schlossman, Love and the American Delinquent: The Theory and Practice of Progressive Juvenile Justice, 1825-1920, at 17 (Chicago, 1977).

99. Peter Stearns, History and Policy Analysis: Toward Maturity, 4 Pub. Historian 14 (1982). 
family and legal history each pose different problems for a merger that hopes to use this unique historical tool. Nevertheless, devising a periodization scheme for the nineteenth century that blends legal and family history can demonstrate some of the benefits to be gained by integrating institutional and sociocultural perspectives into the two subdisciplines.

American family history does not have a fully articulated set of periods. Instead, one major division, the transition from premodern to the modern, has dominated the attempt to find demarcations in the family's past. The commonly accepted turning point lay in the late eighteenth and early nineteenth centuries. Schemes for periodization after the early nineteenth century are "lost in a flurry of statistics about family size and structure in different American cities." ${ }^{100}$ As a result, the shift from premodern to modern has attracted most periodization commentary. In fact, historian Joyce Appleby has argued that family historians, like other social historians, have relied far too much on modernization theory as an organizational base. That is, in trying to pull together phenomena ranging from falling fertility rates to companionate marital customs, historians have adopted a scheme of change that assumes the changes themselves are evidence of a coherent package of modernizing tendencies-exemplified in this case by smaller families, gender equality, and child-centered homes. The result, she says, has been a failure to understand fully the character of family change. ${ }^{101}$

The problem of periodization in family history is but one example of the larger problem in social history: No replacement has been found for the presidential synthesis. Before the burst of the new social history in the 1960 s, most American historians relied on a demarcation of the past tied to major political turning points such as the Revolution, the presidency of Andrew Jackson, and the Civil War. Social historians then demonstrated that few causal links existed between such events and the phenomena they studied, such as changes in occupational mobility or patterns of urbanization. As a result, the political base of American history's periodization began to erode.

But nothing has replaced it. Indeed, as Stearns contends, the centrifugal tendency of topical history not only "reflects a lack of broader conceptualization but also positively hinders the development of an appropriate sociohistorical periodization, sometimes even periodization for a single topic." ${ }^{102}$ More pointedly, after surveying American family history, Ryan lamented: "[t]he historian's craving for exact periodization remains unsatisfied." ${ }^{103}$ Perhaps by tieing social history to institutional history, the legal history of the family can suggest one means of satisfying that hunger. Stearns, for one, thinks that the increased range of interests among social historians has allowed them to relate "to more conventional historical approaches in

100. Ryan, supra note 5, at 184; and see Stone, supra note 7, at 75-76.

101. Joyce Appleby, Value and Society, in Jack P. Greene \& J. R. Pole, eds., Colonial British America: Essays in the New History of the Early Modern Era 306-11 (Baltimore, 1984); and see Ryan, supra note 5, at 185; Degler, supra note 40, at 317-18; Stearns, supra note 49, at 218-20.

102. Stearns, supra note 49 , at 224.

103. Ryan, supra note 5 , at 185 . 
new ways" and led them "to a consideration of broad-gauged periodization on the basis of belief and behavior."104

One advantage of nineteenth-century legal historiography is the existence of a rather well-defined periodization scheme. There are now two reigning typologies: the progression from "release of energy" to "the control of the environment" described by Willard Hurst, and the shift from "instrumentalism" to "formalism" described by Morton Horwitz. ${ }^{105}$ These models of legal change, drawn almost exclusively from studies of commercial law, differ more in assessments of cause and effect than in periodization. They suggest the interrelated nature of nineteenth-century legal change. In fact, they conform to a sequence of legal development that harkens back to Roscoe Pound's seminal work of 1938, The Formative Era of American Law. ${ }^{106}$ So potent has this periodization scheme been that legal historian Stanley Katz fears its assumed discontinuity between provincial and republican America has resulted in a pervasive disregard for colonial legal history. In an effort to revive colonial legal history, Katz fruitfully reminds us that "periodization is a substantive rather than a procedural issue." 107

In that vein, the Hurst and Horwitz schemes pose difficulties once more because of their evidentiary base. Each assumes a uniform pattern of change in all branches of law within and between periods. Yet that is merely an assumption, one that requires proof and one that presently may obscure the distinctiveness of various categories of law. For instance, neither "release of energy" to "control of the environment" nor "instrumentalism" to "formalism" captures the essence of change in family law. Instead, findings of family historians on issues such as the emergence of feminine domesticity in antebellum America and the rise of antiabortion crusades in the 1850s and 1860 s can be used to critique legal history's periodization nomenclature if not its methods. Nineteenth-century domestic relations law, thus, may indicate the need for a new framework that can accommodate the numerous studies of commercial law as well as the emerging legal and social histories of the family, crime, race, religion, and other parts of the American legal past. By grounding periodization in a full range of nineteenth-century experience, not only will the context be enriched but the interrelationships of various seemingly unrelated phenomena can be recognized.

\section{The Changing Eras of Bastardy Law}

The law of bastardy will be used as a limited case study to identify the existence of distinct eras in the history of the law of the family. Making use of a temporal framework, the discussion will extend my assertions about the effects of sociocultural factors on legal change and the judiciary's role as assimilators and directors of legal change.

104. Stearns, supra note 49 , at 229.

105. James Willard Hurst, Law and the Conditions of Freedom in the Nineteenth Century United States (Madison, Wis., 1956); Horwitz, supra note 14, at chs. 1, 8.

106. Roscoe Pound, The Formative Era of American Law (Boston, 1938).

107. Stanley Katz, The Problem of a Colonial Legal History, in Greene \& Pole, supra note 101, at 469. 
Bastardy law suggests that the creation of an American family law occurred in two distinct periods. These ran roughly from the 1790 s to the 1840 s and from the 1840 s to the end of the century. Enough significant policy departures were taken in each that they can be marked off from each other and from the broader sweep of the history of American family governance. The most significant changes occurred in the first period, one that can be labeled the formative era of domestic relations law-using the terms but not the substance of Pound's schema. Revision and consolidation dominated the second period. Together the developments of both periods produced an American law of domestic relations. And they indicate how domestic relations law corresponds to family historians' concern with the shift from premodern to modern and legal historians" concern with "release of energy" and "instrumentalism" shifting to "control of the environment" and "formalism."108

The issue of bastardy is particularly useful in this regard because the classification "illegitimate" is so obviously a social, legal, and economic construct. Not surprisingly, it has been the subject of some work in family history, though primarily in England and generally as a question of demography. ${ }^{109}$ Yet, bastardy has a legal history as well. In nineteenth-century Ameri$\mathrm{ca}$, that history has a set of time frames common to other titles in domestic relations law.

Bastards, as Anglo-American law had long classified children born out of wedlock, traditionally faced legal repression and discrimination. Statutes, doctrines, and customs used matrimony to separate legal from spurious issue. The latter suffered under the legal status of fillus nillius, the child and heir of no one. For centuries under English law, the bastard had no recognized legal relations with his or her parents, and no claims to inheritance, maintenance, or family membership. Nor did the illicit couple have any rights or duties toward the child.

The English reluctance to help bastards was evident in their refusal to follow the civil law and allow legitimation by the subsequent marriage of the parents. The only major reform in the law came with the inclusion of bastards in the Elizabethan Poor Laws and the demand that parents aid in their upkeep. Bastardy law had two primary purposes: repelling challenges to established family organization, especially property distribution, and preventing the public from being saddled with the costs of rearing children born out

108. For a more thorough discussion of this issue and other examples see Michael Grossberg, Guarding the Altar: Physiological Restrictions and the Rise of State Intervention in Matrimony, $26 \mathrm{Am}$. J. Legal Hist. 197 (1982). For similar presentations of family law's periodization see Stanley N. Katz, Legal History and Family History: The Child, the Family, and the State, 21 B.C.L. Rev. 1025-36 (1980); F. Raymond Marks, Detours on the Road to Maturity: A View of the Legal Conception of Growing Up and Letting Go, 39 Law \& Contemp. Probs. 78-92 (1975).

109. See, e.g., Peter Laslett et al., eds., Bastardy and Its Comparative History: Studies in the History of Illegitimacy and Marital Nonconformism in Britain, France, Germany, North America, Jamaica and Japan (Cambridge, Mass., 1980); Jenny Teichman, Illegitimacy: An Examination of Bastardy (Ithaca, N.Y., 1982). 
of wedlock. Colonial Americans, beyond their streamlining of paternity hearings, seem to have made few alterations in this law. ${ }^{110}$

After the Revolution, though, many Americans began to question the traditional purposes of bastardy law. Growing concern over the welfare of the illegitimate child, related to a new view of the child and a new determination to confer certain rights on its mother, helped transform the law. Declining rates of illegitimacy and challenges to active state regulation of sexual behavior sped the search for new policies. ${ }^{111}$

Important here, these post-Revolutionary developments in bastardy law disclose an unnoticed substantive and chronological correspondence between legal and family change. Stages of life have been one of the most studied issues in family history. Specifically, demarcating developmental and attitudinal stages in childhood has been one of the central elements in interpretations about the emergence of the modern family in post-Revolutionary America. Though disagreements persist, particularly over when the changes occurred and how to measure the impact of the new views, most historians now agree that as part of a new family organization and ethos, children came to be seen more precisely than ever before as vulnerable, malleable charges with a special innocence and with particular needs, talents, and characters. While functionalist arguments about the declining role of the family due to industrialization have been largely repudiated, clearly other institutions such as the common school and the church began to share its duties. But molding the nation's young into virtuous republicans and competent burghers became more than ever before the primary responsibility of the family. The widely held conceit that America represented the future and that youth must be reared to fulfill the Republic's manifest destiny magnified the significance of child rearing. The burden fell most heavily on mothers because of the era's dogmatic faith in domesticity, but it affected all family members and all those involved with household affairs. In other words, this is yet another example of the kind of sociocultural factors that influenced the nature and direction of legal change as well as the developments within nineteenth-century American homes. ${ }^{112}$

110. 1 William Blackstone, Commentaries on the Laws of England 454-60 (4 vols. London, 1765-69); William Bartless, Illegitimacy and Legislation, 54 Am. L. Reg. 576-77 (1920); Horace H. Robbins \& Francis Deak, The Family Property Rights of Illegitimate Children: A Comparative Study, 30 Colum. L. Rev. 310-30 (1930); Lawrence Stone, The Family, Sex, and Marriage in England, 1500-1800, at 516-48 (London, 1977); Dominik Lasok, Virginia's Bastardy Laws: A Burdensome Heritage, 9 Wm. \& Mary L. Rev. 411-40 (1967); Hendrik Hartog, The Public Law of a County Court: Judicial Government in Eighteenth Century Massachusetts, 20 Am. J. Legal Hist. 299-308 (1976).

111. For the general context of the era see Smith \& Hindus, supra note 46 at 537-39, 549; Robert Wells, Illegitimacy and Bridal Pregnancy in Colonial America, in Peter Laslett, ed., Bastardy in Comparative History 366-56 (London, 1976); Daniel Scott Smith, The Long Cycle in American Illegitimacy and Premarital Pregnancy, in id., at 372; and see Laslett, supra, Introduction.

112. The most notable features of this new view of the history of children include assertions that for the first time children were seen as quite distinct from adults, and childhood was recognized as a separate developmental period. Moreover, child rearing became the most important responsibility of the home. Bernard Wishy, The Child and the Republic: The Dawn of Early American Child Nurture (Philadelphia, 1968); Robert H. Bremner et al., eds., Children and Youth in American History vols. 1 \& 2 (Cambridge, Mass. 1970); Daniel Calhoun, The Intelligence of the People 134-205 (Princeton, N.J., 1973). For a recent 
Yet the relationship between these new views of children and the law remains unstudied. Indeed except for a few studies of schooling, the institutional elements of the history of childhood are unexamined. Seemingly relevant research in institutional history, such as David Rothman's work on the creation of asylums for juveniles, ${ }^{113}$ does not directly address the issues posed by legal historiography. His study concentrates on the repressive character of reformers and the institutions they created, without placing either in clear legal context. Instead, he assumes that statutes and common law either codified reform demands or were irrelevant. Yet in a compelling study of antipatriarchalism in the Revolutionary era, literary critic Fliegelman postulates that the "new parenting and the constitutional government were intimately related." "114

More to the point, though, nineteenth-century bastardy law reveals some implications of integrating the study of legal and family change in the era. State after state rewrote its bastardy laws after the Revolution. Statutes and judicial decisions declared the offspring of a couple who wed after its birth to be legitimate. They did the same for the children of annulled marriages and, thus, eased the process of legitimating children by legislation. ${ }^{115}$ In 1830 Chancellor James Kent explained the logic of the changes: "This relaxation in the law of so many states of the severity of the common law, rests upon the principle that the relations of parent and child, which exists in this unhappy case in all its native and binding force, ought to produce the ordinary legal consequences of that consanguinity." 116

Perhaps more evocatively, in 1837, Ohio legal educator and reformer Timothy Walker hailed bastardy law reform as a republican repudiation of aristocratic, overly property-conscious English law. He wondered how the "justice and humanity" of the new acts could not "fail to strike every mind." In a typical assertion of the individual rights ideology of the era, Walker dismissed the traditional policies as "cruel and unreasonable" because they visited "the sins of the parents upon the unoffending offspring of their unlawful intercourse." Penalty without responsibility violated republican ethics; new views of children sensitized men like Walker to this particular transgression. He proclaimed the rewritten bastardy laws as "wise and humane" because they gave "to such parents the strongest of motives to repair

revisionist account of the history of childhood that questions some of these points see Linda A. Pollack, Forgotten Children, Parent-Child Relations from 1500 to 1900 (Cambridge, England, 1983). For a discussion of the significance of the stages of life issue see Stone, supra note 7, at 68 .

113. David Rothman, The Discovery of the Asylum (Boston, 1971). For an attempt to link family and legal change in the colonial and post-Revolutionary era see Peter Hoffer \& N. E. H. Hull, Murdering Mothers: Infanticide in England and New England, 1758-1803 (New York, 1981).

114. Fliegelman, supra note 24, at 161 .

115. Senser v. Bower, 1 Pa. 450 (1834); Commonwealth v. Stricker, 1 Browne Appendix 47, 48-50 (Pa. 1801); Van Aernam v. Van Aernam, 1 Barb. Ch. 375, 376 (N.Y. 1846); Davis v. Henderson, 2 Yeates 289 (Pa. 1798); Stones v. Keeling, 9 Va. (5 Call) 143, 146-47 (1804); Hartwell v. Jackson, 7 Tex. 576 (1850); McCormick v. Cantrell, 15 Tenn. (7 Yer.) 615 (1835); Pigeau v. Duvernay, 4 Mart. 265 (La. 1816); Sleigh v. Strider, 9 Va. (5 Call) 439 (1805); 2 Kent, supra note 61, at 211-12; William Griffith, Annual Survey of American Law (New York, 1822), vols. 2, 3 passim.

116. 2 Blackstone, supra note 110 , at 214. 
by subsequent marriage, the wrong they will otherwise have done." To Walker and many others, "such improvements in the law, cannot be too much commended, cannot fail to purge the law of a multitude of doctrines unsuited to the present state of civilization." 117

And reform did not stop there in this formative era of domestic relations law. Even if parents failed to wed, other legal departures lessened the penalties of illegitimacy. The most significant are yet another example of the judicial exercise of patriarchal authority in American family law and the role of judges as assimilators of new social beliefs into the law. In this case, judicial innovations created a new legal household and bound it together with inheritance rights. State appellate judges turned the customary bonds between the bastard and its mother into a web of reciprocal rights and duties. The judiciary granted these women custody rights in a reinterpretation of the law that combined the new faith in maternal care with a post-Revolutionary assertion of judicial authority over the allocation of domestic rights and responsibilities. As a panel of New York judges declared in 1807: "in the case of illegitimate children, and especially as to females, the mother appears to us to be the best entitled to the custody of them; but this right is not of such a nature as to prevent the court from interfering to take the infant from the custody of the mother under special circumstances of ill-treatment." "118 Twenty years later Kent presented maternal preference as the uncontroverted rule of American common law. ${ }^{119}$

Similarly, judges and legislators began to confer reciprocal inheritance rights on bastards and their mothers and on other kin. The 1837 Virginia case of Garland $v$. Harrison highlights the character of these changes and the post-Revolutionary consciousness with which they were done. In that case, Justice St. George Tucker reversed a lower court decision that, he argued, had misunderstood the state's republican heritage and cleaved too closely to English biases. Explicitly noting the shift in thought, he asserted: "After the termination of the revolution, when a revision and radical change of much of our system of jurisprudence became indispensable, other counsels prevailed as to the law respecting bastards as well as in relation to inheritance generally." ${ }^{20}$ The elimination of primogeniture and the creation of inheritance rights for bastards became part of the state code because "our law of descents was formed in no small degree upon the human affections, and the legislature very justly conceiving that the object of our law of descents was to supply the want of a will, and that it should therefore conform in every case ... to the probable current of those affections which would have given direc-

117. Timothy Walker, Introduction to American Law 233 (Philadelphia, 1837).

118. People v. Landt, 2 Johns. 375, 376 (N.Y. 1807); and see Wright v. Wright, 2 Mass. 109 (1806); Hudson v. Hills, 8 N.H. 417 (1836); Carpenter v. Whitman, 15 Johns. 208 (N.Y. 1818); Canaan v. Salisbury, 1 Root 155 (Conn. 1790); Bethlem v. Roxbury, 20 Conn. 298 (1850); Petersham v. Dana, 12 Mass. 428 (1815); Westfield v. Warren, 8 N.J.L. 249 (1826).

119. 2 Kent, supra note 61, at 215-16; Rollin C. Hurd, A Treatise on the Right of Personal Liberty 522-27 (Albany, N.Y., 1858); Lewis Hochheimer, A Treatise Relating to the Custody of Infants 382-92 (Baltimore, 1889).

120. 35 Va. (8 Leigh) 368 (1837). 
tion to the provisions of such will." ${ }^{121} \mathrm{He}$ asserted that the legislature had intended the illegitimate child to become a member of his or her mother's family, sharing in property as well as in household life. The purpose of the law, the court concluded, was to "abolish this distinction, to a certain extent, between legitimate and illegitimate children, and to endow the latter with inheritable blood on the part of the mother." ${ }^{122}$ By doing so, Tucker assumed that the perils of illegitimacy could be eased by creating a web of rights and duties within private family law-a key determination of the law's formative era. ${ }^{123}$

Through decisions like this the judiciary framed the language of American domestic relations law and made the years from 1790 to 1840 its formative era. Indeed, as the other examples in this essay indicate, these were critical years in the development of American family law. The bastard began to have his or her own set of rights and responsibilities at the same time that the courts began to reformulate the rules governing seduction under the cover of a promise to marry and the treatment of runaway marriages. In the case of bastards, legislators and judges relied on new notions of the welfare of the child and the rights of its mother (the two main family beneficiaries of the rights consciousness embedded in post-Revolutionary legal ideology) to sever family membership from punishment for sexual immorality and property protection. Similarly, this periodization scheme parallels the form if not the content of periodization in legal and family history; it also is in accord with the sequence of change in women's history. ${ }^{124}$ Historians like Nancy Cott, Mary Beth Norton, and Linda Kerber have argued that the post-Revolutionary era witnessed a redefinition of women's roles and responsibilities through the rise of greater feminine autonomy, the institution of the idea and practice of domesticity, the emergence of companionate marriage, and the beginning of a century-long fall in fertility rates. ${ }^{125}$ Drawing on their work, legal historian Richard Chused concludes that the "stage was set for a cultural redefinition of the married women's separate sphere." 126

Yet innovations are only one part of the era; continuities-the other pole of periodization-existed as well. American bastardy law never jettisoned two traditional influences: fiscally conservative local officials anxious to control child support costs, and a deeply ingrained prejudice against extramarital sexual relations. Most likely, changes in the law aided those mothers

121. Id. at 389 .

122. Id. at 372 .

123. And see Cooley v. Dewey, 21 Mass. (4 Pick.) 93 (1826); Lange v. Richous, 6 La. 560 (1834); Earle and McNier v. Dawes, 3 Md. Ch. 230 (1849); Kelly's Heirs v. McGuire and Wife, 15 Ark. 555 (1855); Flintham v. Holder, 16 N.C. (1 Dev. Eq.) 349 (1829); Littlev. Lake, 8 Ohio 289 (1838); Miller v. Stewart, 8 Gill 12 (Md. 1849); Brown v. Dye, 2 Root 280 (Conn. 1795); Woodstock v. Hooker, 6 Conn. 36 (1825); Burlington v. Fosby, 6 Vt. 83 (1834); Kent v. Barker, 68 Mass. (2 Gray) 535 (1854); Tapping Reeve, A Treatise on the Law of Descents 96 (New York, 1825); 2 Kent, supra note 61, at 212-14; Griffith, supra note 115, vols. 1 \& 2 .

124. For a similar analysis of the impact of the Revolution on inheritance law see Stanley N. Katz, Republicanism and the Law of Inheritance in the American Revolutionary Era, 76 Mich. L. Rev. 1 (1976).

125. See Cott, supra note 31; Mary Beth Norton, Liberty's Daughters: The Revolutionary Experiences of American Women, 1750-1800 (Boston, 1980); Kerber, supra note 14; Lebsock, supra note 14.

126. Chused, supra note 33, at 1415. 
and couples who could support their offspring and thus further segregated impoverished mothers and couples within family law. Parents who relied on poor relief for sustenance probably never acquired a significant portion of these new rights. Protection of taxpayers' pocketbooks reinforced a general conviction that proper child nurture required guardians capable of providing adequate material support. As the Vermont Supreme Court asserted, with no irony intended, the illegitimate child "has the same rights as any pauper when its custody is shifted from one keeper to another." ${ }^{127}$ Just what that set of dependent rights might be has not been examined very thoroughly by legal or family historians.

In addition, the post-Revolutionary changes had little impact on paternity hearings. They continued to be dominated by fiscal fears and the trappings of criminal law. The proceedings were guided by gender biases as well, particularly the assumption that nurture was a maternal responsibility, support a paternal one. University of Chicago law professor Ernst Freund's 1919 description of American illegitimacy law would have been applicable a century earlier: "It is apparent that the law of bastardy is controlled by standards of poor relief. In any event, the alimony is measured by the mother's and not the father's position in life, and although the law may not express it that way, it is in the nature of an assistance to her." ${ }_{128}$

\section{A New Legal Era}

Post-Revolutionary bastardy law's distinctive combination of tradition and innovation spread across the nation after the 1840s. Its central tendencies became orthodoxies and entered the codes and reports of almost every jurisdiction. The gradual diffusion of these policies is a graphic example of incremental development, one of the salient features of the second era of nineteenth-century family law. ${ }^{129}$ As in many areas of domestic relations, a

127. Adams v. Adams, 59 Vt. 158, 161 (1877). For illustrations of class and culturally biased uses of the law see Philadelphia v. Bristol, 6 Serg. \& Rawle 502 (Pa. 1819); Boylston v. Princeton, 13 Mass. 381 (1816); Manchester v. Springfield, 15 Vt. 385 (1843); Robalina v. Armstrong, 15 Barb. 247 (N.Y. 1852); Byrne v. Love, 14 Tex. 81 (1855); and see Bloomfield, supra note 72, at 122-35. For a particularly insightful recent assessment of the policy implications of nineteenth-century poverty and dependency see Katz, supra note 87.

128. Illegitimacy Laws of the United States 42 (Washington, D.C., 1919); and for examples of this aspect of bastardy law see Schooler v. Commonwealth, $16 \mathrm{Ky} .88$ (1809); Hinman v. Taylor, 2 Conn. 357 (1817); Moncrief v. Ely, 19 Wend. 405 (N.Y. 1838); State v. Goode, 32 N.C. (10 Ired.) 49 (1849); Morse v. Pineo, 4 Vt. 281 (1832); Spalding v. Felch, 1 Root 319 (Conn. 1791); Johnson v. Randall, 7 Mass. 340 (1811); Cooper v. State, 4 Blackf. 316 (Ind. 1837); Shenk v. Mingle, 13 Serg. \& Rawle 28 (Pa. 1825); Burgen v. Straughan, 7 J. J. Marsh. 583 (Ky. 1832); Coleman v. Frum, 3 Scam. 378 (Ill. 1842); 2 Kent, supra note 61, at 216-17; William Rockel, Evidence in Bastardy Cases, 18 Cent. L.J. 305-7 (1884).

129. For examples of the process of diffusion in various categories of bastardy law, see Egbert $v$. Greenwalt, 44 Mich. 245 (1880); Fox v. Burke, 31 Minn. 319 (1883); Herring v. Goodson, 43 Miss. 392 (1870-71); Hawbecker v. Hawbecker, 43 Md. 516 (1875); Crane v. Crane, 31 Ia. 296 (1871); Pina v. Peck, 31 Cal. 359 (1866); Dickenson's Appeal from Probate, 42 Conn. 491 (1875); Bales v. Elder, 118 Ill. 436 (1887); Keeler v. Dawson, 73 Mich. 600 (1889); State v. Noble, 70 Ia. 174 (1886); Frederic Stimson, American Statute Law $\S \S 3151,6620-6622,6631-6636$ (Boston, 1886); 4 Vernier, supra note 80, at 150-52, 178-82, 190-92; Frank Fessenden, Nullity of Marriage, 13 Harv. L. Rev. 110 (1899-1900); Florence Kelly, On Some Changes in the Legal Status of the Child Since Blackstone, 13 Int'l Rev. 96 (1882). 
new balance of innovation and tradition became routine as it elicited the support of increasing numbers of judges, legislators, and commentators. Bastardy law's history became the vital but mundane story of refinement- the zeal of the formative era giving way to the routine of a period of consolidation.

Yet there is more to the tale; other issues emerged to place illegitimacy and law into a new context. The legal record indicates that a point existed in the logic of nineteenth-century American legal reform beyond which the law would not be used to assist children born out of wedlock. That point can be found in a new era in bastardy law that began in the 1840s and continued into the early twentieth century.

The post-1840 obsession with protecting the family that propelled family savers into action against runaway marriage also reinvigorated the use of law to separate legitimate from illegitimate children. Links between family law and fears about social disorder are evident in the very character of major legal reforms after 1840, paralleling a general shift in reform tactics that historian Charles Rosenberg has termed "a growing biological reductionism and emphasis on authoritarian solutions." Reform generally came by way of augmented state authority over specific elements of family life, such as restrictive divorce statutes, bans on abortion, compulsory school laws, and antidesertion legislation. Though unrecognized as such by historians of social reform, the changes were often aimed at overturning common law doctrines through statutory initiatives. The new strategies suggest that many of the authors of American domestic relations law, especially family savers and their legislative allies, began to lose confidence in the private regulation of the family backed by a reliance on litigation for dispute settlement. Those had been hallmarks of the law's formative era. The nature of the shift in periods is evident in the recent comments of two social historians who argue that late nineteenth-century family regulation carried "an implied threat that if the family did not produce persons of the right type, it could go into receivership and have its human assets (especially children) directly managed by the state." 130

Despite such assertions, neither family nor legal historians have paid much attention to the nineteenth-century family crisis and its legal implications. Those that have, such as James Mohr, Linda Gordon, David Pivar, and James Reed, have generally examined particular social reforms such as antiabortion, birth control, and social purity, or topics such as feminism, professionalization, or institution creation. ${ }^{131}$ The dual themes of elite reform and social control dominate this literature. The broad relationship of the family crisis to household practice or legal development has not been explored to

130. Charles Rosenberg, The Bitter Fruit: Heredity, Disease, and Social Thought in Nineteenth Century America, 8 Persp. Am. Hist. 223 (1974); Busacca \& Ryan, supra note 14, at 85. For a further discussion of this point see Grossberg, supra note 108.

131. Mohr, supra note 86; Linda Gordon, Woman's Body, Woman's Right: A Social History of Birth Control in America (New York, 1974); James Reed, From Private Vice to Public Virtue: The Birth Control Movement and American Society Since 1830 (New York, 1978); David Pivar, The Purity Crusade: Social Morality and Social Control, 1868-1900 (Westport, Conn., 1968). 
any significant extent. Nevertheless, these studies suggest a periodization scheme that is complementary to the one proposed here.

Legal historians have also ignored the issue. That is a bit more surprising because family law reform took place at precisely the same time as new forms of state economic regulation. These commercial law changes form the basis of legal historians' two main periodization schemes. Railroad and mining regulatory measures are evidence Hurst relies on for his shift from "release of energy" to "control of the environment"; and judicial defenses of earlier common law doctrines beneficial to commercial elites against intrusive legislation constitute the sources of Horwitz's claim of the rise of legal formalism. Again the basis for a broader periodization scheme exists in a dormant state. ${ }^{132}$

Neither the social historians' fascination with elite reformers and social control nor the legal historians' generalizations of commercially based change fully capture the nature of family law revision. For example, domestic relations law suggests that both may have overemphasized intervention and attributed to it successes never achieved. Also illustrative of the era's character are its failures. Bastardy reform is one of these; it is in some ways a negative example of the period's environment. The main point is that nothing much happened despite renewed agitation. Little support existed in this second period of nineteenth-century family law for expanding the rights of bastards any further, and there was almost none for the occasional call to abolish the status of bastardy itself. Instead of expanding legal rights for bastards as part of a continuing promotion of family privacy and individual autonomy, bastardy law indicates that a new set of issues dominated this period of domestic relations law.

Investigation of the squalid cities of industrial America by muckrakers and urban social reformers ignited the issue of illegitimacy anew. Particularly important, they documented some of the limits of earlier legal reforms. In fact, their muckraking underscores the need to look inside and outside of the legal order to gauge the impact of legal change; that is, in the terms of this essay, to blend lawyers' and historians' legal history. In this case, despite the widespread diffusion of innovations devised in bastardy law's formative era, reformers uncovered shocking evidence of mistreatment of bastards, higher rates of infant mortality among the illegitimate than among the lawfully born, and a thriving market offering bastard children for sale and barter.

Significantly, in terms of the role of law in the perception of problems, reformers turned to the judicially created "bastard family" as a solution. Kate Waller Barrett made the point quite explicitly: "if we cannot have the trinity which God intended - husband, wife, child - we can have the other trinitymother, child, home - that has a mighty potency in it for doing good." ${ }^{133} \mathrm{~A}$ minority of radical reformers even demanded that bastards be accorded the

132. For an exception to the trend see Keller, supra note 83 , at ch. 12.

133. Barrett quoted in Susan Tiffin, In Whose Best Interest? Child Welfare in the Progressive Era 171 (Westport, Conn., 1981), and see generally ch. 7. 
same legal rights as legitimate children. Reformers were fired by the now orthodox republican rights belief that there "may be illegitimate parents but there can be no illegitimate children." 134

Their major successes, though, were statutes that increased state supervision of bastards and their putative parents. The new acts mainly tightened the procedures governing the most traditional aspects of the law-paternity and support. Perhaps the most profound change in the fate of many illegitimate children came through the gradual exertion of control over bastardy by social workers and welfare bureaucrats. Yet, as welfare professionals took up the cudgel for these unfortunates, the objectives of bastardy law fell into doubt. Bastardy law provides one example of larger struggles within late nineteenth-century domestic relations law. In this case, social workers grappled with trying to achieve what now appears to have been the incompatible goals of preserving republican individualism and economic liberalism while trying to create a more cooperative community and active state. Thus illegitimacy and many other late nineteenth-century domestic relations controversies disclose problems that earlier changes had not resolved. Prime among them was whether or not further aid to bastards would undermine the legal family as it had come to be defined.

The issue tore apart a 1919 social work conference. Bradley Hull, a Cleveland social worker, took to the floor to warn his colleagues: "I think that between the two, there should be an unmistakable preference shown for the marriage state. And I think entirely aside from the legal question, if you put the illegitimate child on a basis of equality with the child born of the man's wedded wife there is a great source of danger." An indignant Minnesota delegate countered: "They are all children, are they not?" But Hull would not give ground: "Yes, but there is something more. The question is, is the child or the home to be the unit of the state? If you are going to make, as far as the economic base is concerned, the status of the unmarried mother and her child equal to that of the married woman and her child, you are going to do something to unsettle society." In a nation congenitally terrified of unsettled homes, the limits of reform had been reached. ${ }^{135}$

\section{Historiographical Significance}

As the periods in nineteenth-century bastardy law reveal, the law did not develop uniformly or along a clearly linear path. Instead it blended innova-

134. Standards of Legal Protection for Children Born Out of Wedlock, Publication No. 77 at 7 (Washington, D.C.: U.S. Children's Bureau, 1921); and see Emma O. Lundberg \& Katharine Lenroot, I1legitimacy as a Child Welfare Problem, Publication No. 66, pt. 1 (Washington D.C.: U.S. Children's Bureau, 1920); Juvenile Protection Association of Chicago, The Care of Illegitimate Children in Chicago (Chicago, 1913).

135. The conference proceedings are recorded in Standards for Children, supra note 134, at 82-93, and see page 27 for Freund's discussion of the issue; see also Children of Illegitimate Birth and Measures for Their Protection 11 (Washington, D.C.: U.S. Children's Bureau, 1926); Keller, supra note 83, at 463; W. Logan McCloy, The Laws of Pennsylvania Relating to Illegitimacy, 7 J. Crim. L. \& Criminology 512 (1916-17); D. H. Van Doren, Rights of Illegitimate Children Under Modern Statutes, 16 Colum. L. Rev. 700 (1916); Ernst Freund, Illegitimacy Laws of the United States (Washington, D.C., 1919); 4 Vernier, supra note 80, at 208-18; Berkeley Davis, The Passing of Illegitimacy, 9 Law Notes 145 (1913). 
tion with orthodoxy in a way that illuminates the dominant features of each period in the creation of an American domestic relations law. These periods in turn suggest that the history of the law of the family both complements and contradicts current generalizations in family and legal history.

Specifically, the periodization of nineteenth-century family law underscores the limitations of one dominant view of the history of domestic relations law. To many lawyers in particular, that history is a progressive record of ever increasing individual rights for family members. In a widely noted article, family lawyer Judith Younger adopted a variation of modernization theory to argue that the present-day crisis in marriage and parenthood is the inevitable product of an uncontrollable individualism that has developed in this country over the last 300 years. ${ }^{136} \mathrm{Her}$ "whiggish" notion of domestic relations posits the slow but certain triumph of individual autonomy and family privacy as both the central force and major product of social change; the eventual transition from patriarchy to equality. In arriving at that conclusion, Younger did not consult recent work in family and women's history. Had she done so, she would have discovered that historians challenge assertions about uniform linear change. They point to countless examples of varied family experiences due to class, regional, ethnic, and racial differences. Indeed, she would have found a vigorous debate over the very nature of individual family members' rights in the past because of such variations. The legal history of bastardy mentioned here is but one example of a part of the family's past in which individual rights were consistently subordinated to notions of public interests quite at odds with a progressive view of rising individual autonomy. ${ }^{137}$

The continuities and discontinuities in the nineteenth-century history of a domestic relations law topic such as bastardy indicate why assertions of continuous, uniform change need to be assessed much more critically than they have been. Breaking the nineteenth-century history of family law into periods reveals the distinctive features of the law's formative and consolidation periods and demonstrates that there is no single thread of development that cuts across all American families at all times. Indeed, as Stone declared emphatically in his review of family history: "There has never been a French family or an English family or an American family, but rather a plurality of families." "138 The judicially created bastard family is but one example of the variations in nineteenth-century American households, as are the couples involved in runaway marriages and the women who sued when their beaux broke their marriage promises. Periodization, then, emphasizes both the changing context and the constant mix of change and continuity in American family law.

136. Judith Younger, Marital Regimes: A Story of Compromise and Demoralization, Together with Criticism and Suggestions for Reform, 67 Cornell L.Q. 45 (1981).

137. For a discussion of these issues see Chused, supra note 46; Norma Basch, In the Eyes of the Law: Women, Marriage and Property in Nineteenth Century New York (New York, 1982); Marylynn Salmon, The Legal Status of Women in Early America: A Reappraisal, 1 Law \& Hist. Rev. 129 (1983).

138. Stone, supra note 7, at 81; and see Ryan, supra note 5, at 186-87. 
In a related way, domestic relations topics like bastardy open new vistas on perennial questions in American legal history. For example, judicial actions in domestic relations offer little support for blanket generalizations about the judiciary, such as the common claim among legal historians that a rigid legal formalism arose late in the nineteenth century. Though committed to a common law in which many major innovations had occurred earlier in the century, the courts were hardly slavish proponents of existing doctrines, a corporate clientele, pseudo-science, or political conservatism, as traditional accounts of formalism contend. ${ }^{139}$ Nor did their allegiance to common law forms over statutory initiatives in domestic relations law originate solely in a determination to prevent the redistribution of power and wealth, as Horwitz's revision of formalism would have it. ${ }^{140}$ Indeed, in family law, that goal was as likely to be held by reformers like the Reverend Dike as by judges. Rather, the judicial commitment to bastardy law and conflict of law doctrines occurred within a complex political debate in which states' rights, federalism, institutional power plays, fears of centralized authority, new theories of childhood, republican individual-rights ideology, and related commitments often made the judicial position attractive and compelling to many participants and repellent to others. ${ }^{141}$

This complexity is lost in reigning views of formalism that depict it simply as a blind commitment to the past allocations of power and wealth in the face of unwanted changes in the present. As Charles Goetsch has argued recently, "American legal historians have arrived at the point where we must now begin to clarify and refine the concept of legal formalism by firmly grounding it in the complex detail of the reality it was created to describe." 142 The continued reliance on some elements of the judicial approach to bastardy indicates the need to understand the legal changes of the era in ways that explain a phenomenon like formalism in a much broader context.

\section{Conclusion: The Challenge of}

\section{AMERICAN DOMESTIC RELATIONS LAW}

The central proposition of this essay-that much is to be gained by merging legal and family history - would not have surprised James Schouler, the leading nineteenth-century chronicler of domestic relations law. A lawyer and historian, Schouler's work in history and law earned him a reputation as a leading treatise writer and the presidency of the American Historical Association. In 1870 he published The Law of Domestic Relations, the first com-

139. See Morton White, Social Thought in America: The Revolt Against Formalism (Boston, 1957); Benjamin Twiss, Lawyers and the Courts (New York, 1942); Arnold M. Paul, Conservative Crisis and the Rule of Law: Attitudes of the Bench and Bar, 1887-1895 (New York, 1960).

140. Horwitz, supra note 14 , at ch. 8 .

141. For a compelling view of legal ideology in this era see Robert Gordon, The Ideal and the Actual: Fantasies and Practice of New York Lawyers, 1870-1910, in Gerhard Gawalt, The New High Priests, Lawyers in Post-Civil War America 51-74 (Westport, Conn., 1984).

142. Charles C. Goetsch, The Future of Legal Formalism, 24 Am. J. Legal Hist. 255 (1980); and see Robert Gordon, Historicism in Legal Scholarship, 90 Yale L.J. 1037 (1981); Morton Horwitz, The Historical Contingency of the Role of History, id., 1057-59. 
prehensive presentation of American family law. ${ }^{143}$ As Horwitz has persuasively argued, the appearance of a treatise in a new field "is almost always an important clue to when a specific subject area has begun to crystallize."144 That was certainly the case with domestic relations law. Schouler's treatise is a revealing compilation of the major doctrines, biases, contradictions, and other fundamental elements of a now dense legal category. It is, thus, a fitting summary of this foray into nineteenth-century American family law.

Domestic Relations should be read as a relic of the nineteenth-century merger of the family and the law. It documents how interrelated developments blended tradition and innovation to form a distinctive American family law. Like statutes, judicial decisions, reform tracts, popular periodicals, and other legal commentaries, Schouler's volume depicts the family as a special institution and its law as a particular legal category. The treatise also indicates that such functional and ideological line drawing had substantive results. The creation of a category for domestic relations was part of the broader movement toward specialization within the legal order. Not only did the legal system become a thicket of specialized rules, procedures, and institutions; more important, each segment spawned its own set of interests, concerns, and techniques. Consequently, in spite of repeated assertions of the law's conceptual uniformity, nineteenth-century family law was never a mere offshoot of the legal order's commercial branches; the relationship between the two and the other branches of the law was much more complex.

Capturing the elusive nature of nineteenth-century family law was (and is) difficult. Schouler tried to do so in an 1895 revision of his treatise:

The law of the family is universal in its adaptation. It deals directly with the individual. Its provisions are for man and woman; not for corporations or business firms. The ties of wife and child are for all classes and conditions; neither rank, wealth, nor social influence weighs heavily in the scales. To everyone public law assigns a home or a domicile, and that domicile determines not only status, capacities, and rights of the person, but his title to personal property. ${ }^{145}$

Schouler caught the distinctive categorization that consigned family governance to a special place in the American legal order. But the law itself eluded even its leading commentator.

The intense public and private interests, conflicts, and fears inspired by the family and visible in the legal record helped generate a body of law that defied Schouler's simple summation. As it emerged in nineteenth-century America, family law rested on several central assumptions. The most important of these was that the family was a separate realm of experience and that, consequently, the body of law governing the household also should be a separate realm. But as did many other bodies of law, domestic relations had an elusive quality about it. In fact, part of the fascination of the topic and its implications lay in its ambiguous character. At no time was domestic relations

143. James Schouler, A Treatise on the Law of Domestic Relations (Boston, 1970).

144. Morton Horwitz, Part III-Treatise Literature, 69 Libr. J. 461 (1976).

145. Schouler, supra note 143 , at 9. 
an airtight, self-contained body of law. It was rather a conscious construct that not only changed over time but developed in a manner that was neither clearly linear nor uniform. Indeed, domestic relations law was never fully coherent or free from internal conflict. Its particular subjects remained wedded together only under the assumption that, to take its two major subheads, the law of husband and wife and that of parent and child were both aspects of domestic relations as defined by judges, legislators, and the law's other authors.

American family law just could not be easily reduced to a set of clear and certain principles. It remained an amalgam of complex, often contradictory policies that were devised amid shifting concern for governing every aspect of family life from courtship to probate. It is this legal welter that challenged Schouler and should challenge family and legal historians and others interested in questions involving the family and the state. 
